\title{
“WE'RE ALL FRIENDS HERE”: HOW DO EARLY CHILDHOOD EDUCATORS PROMOTE FRIENDSHIP IN THE CLASSROOM?
}

by

\author{
Kimberly Orchard \\ B.A Honours \\ University of Ottawa, 2013
}

A Major Research Paper

presented to Ryerson University

in partial fulfillment of the

requirements for the degree of

Masters of Arts

in the program of

Early Childhood Studies

Toronto, Ontario, Canada, 2015

(C) Kimberly Orchard, 2015 


\section{Author's Declaration}

I hereby declare that I am the sole author of this MRP.

This is a true copy of the MRP, including any required final revisions.

I authorize Ryerson University to lend this MRP to other institutions or individuals for the purpose of scholarly research.

I further authorize Ryerson University to reproduce this MRP by photocopying or by other means, in total or in part, at the request of other institutions or individuals for the purpose of scholarly research.

I understand that my MRP may be made electronically available to the public 


\title{
ABSTRACT \\ “WE'RE ALL FRIENDS HERE”: HOW DO EARLY CHILDHOOD EDUCATORS PROMOTE FRIENDSHIP IN THE CLASSROOM?
}

Masters of Arts, 2015

\author{
Kimberly Orchard \\ Program of Early Childhood Studies \\ Ryerson University
}

This qualitative study set out to explore how five early childhood educators perceive and promote friendship in a toddler room, a preschool room, and a kindergarten room of an early learning center in Ontario, Canada. Semi-structured interviews were conducted to explore educator's perceptions about friendship and their reported strategies for promoting friendship. Observations of each classroom explored educator's strategies used to promote friendship in practice. New sociology of childhood and developmental theoretical frameworks were used to explore educator's perceptions and strategies. Educator's perceptions about friendship were placed on a continuum ranging from perceptions that aligned with new sociology of childhood to developmental theory. The reported and observed strategies were categorized into active, reactive and passive strategies. Implications of these findings for practice, policy, and research were discussed.

Keywords: friendship, educator's perceptions, educational strategies, new sociology of childhood, developmental theory, early childhood education 


\section{Acknowledgements}

I would like to express my gratitude to the following people for helping me complete this project. Thank you to you all for supporting me throughout this process.

First, I would like to thank my supervisor, Dr. Rachel Langford, for sharing your time, opinions, and expertise with me. The amount of care you provide to your students does not go unnoticed. Thank you for your kindness and support.

Thank you to my second reader, Dr. Kathryn Underwood, for taking the time to critically examine my project. I have considered it a privilege to learn from you in a number of different capacities over this past year.

Thank you to Dr. Mehrunnisa Ahmad Ali for chairing my oral defense. Your positivity was greatly appreciated.

I would also like to thank my participants. Thank you for taking the time to meet with me, and for allowing me to observe your classroom. This project was made possible because of you.

Finally, I would like to thank my family and friends for their support during this journey. Mark, your encouragement has been instrumental in my success. Thank you for always being there to inspire me. Mom and Dad, thank you for your love, and for encouraging me to pursue what I love. To my friends who have listened to my ideas and worries throughout this process, thank you for supporting me. I could not have done this without all of you. 


\section{Table of Contents}

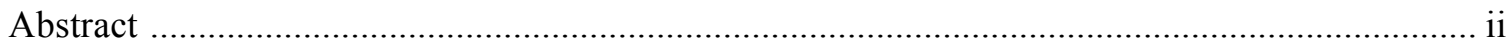

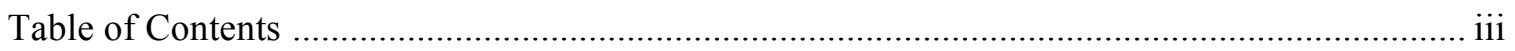

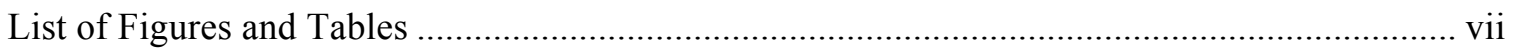

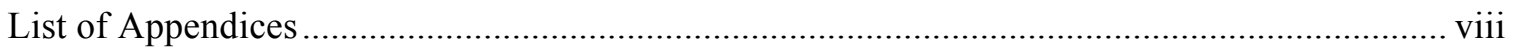

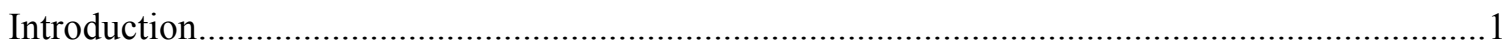

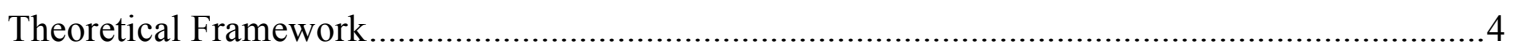

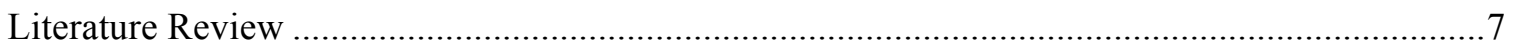

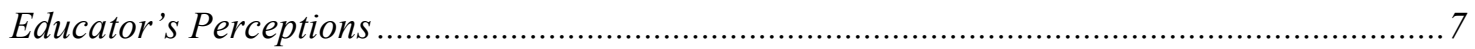

Studying Friendship: Theories and Research Methods .................................................... 10

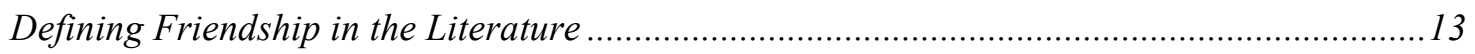

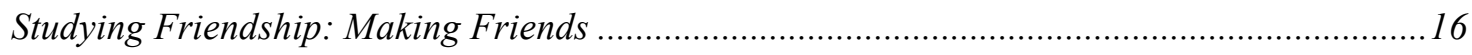

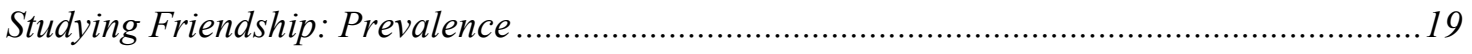

Recommended Strategies to Promote Friendship ...........................................................20

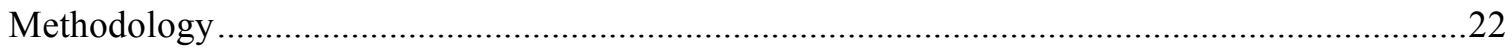

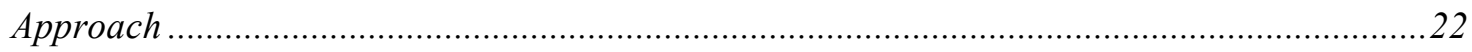

Sample and Recruitment

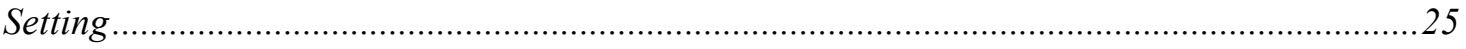

Data Collection Process: Interviews and Observations ...................................................27

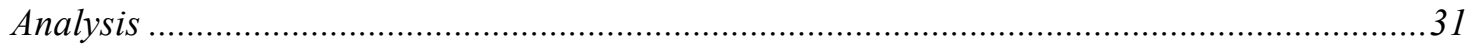

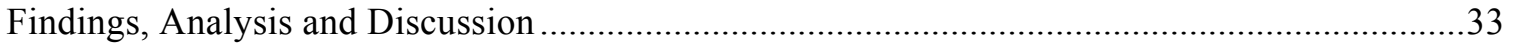

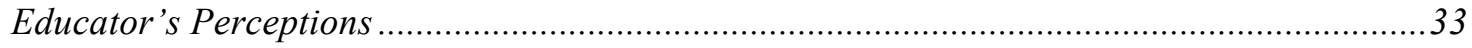

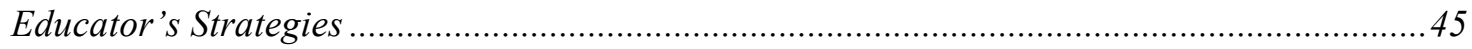

Possible Links Between Educator's Perceptions and Strategies ..........................................60 
Limitations of Study

Future Research ... . .68

Conclusion .68

References...... . .78 


\section{List of Tables and Figures}

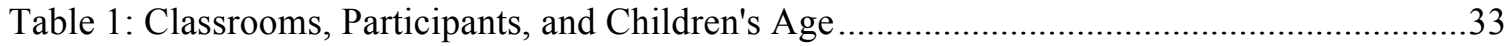

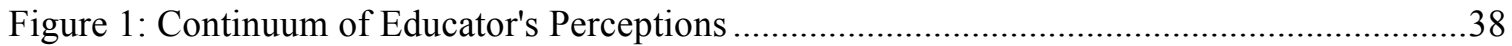

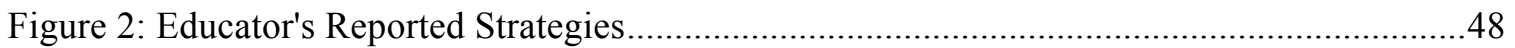

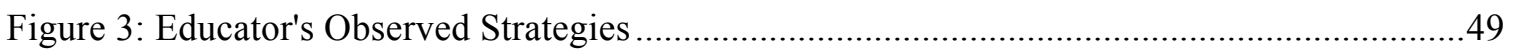




\section{List of Appendices}

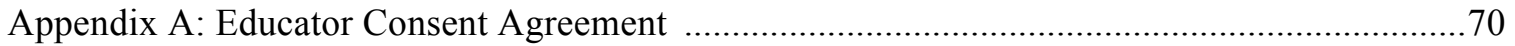

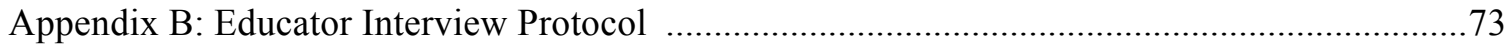

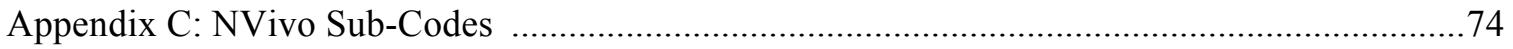

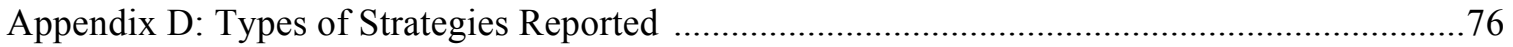




\section{Introduction}

Friendship is often regarded as one of the most important forms of social relationships (Webster \& Carter, 2007). Research has suggested that developing friendship at an early age can have long-term positive effects (van Hoogdalem, Singer, Eek, \& Heesbeen, 2013). Children who have friendships in preschool have been found to have more academic and social success in kindergarten (Ladd, 1990; Rimm-Kaufman, Pianta, \& Cox, 2000). Research has also found that children who have friendships in primary school have increased sociability and leadership in high school (Berndt, Hawkins, \& Jiao, 1999), as well as good job performance, family interaction, social life, and activity involvement in adulthood (Bagwell, Newcomb, \& Bukowski, 1998). Along the same line, children with no friendships in primary school have been found to have an increased chance of loneliness, depression, social anxiety, and suicidal ideation (Bagwell et al., 1998; Ladd \& Troop-Gordon, 2003; Pedersen, Vitaro, Barker, \& Borge, 2007). A recent 18-year longitudinal study reported that adults who had no friendships as a child had statistically higher odds of psychological difficulties than children who had at least one friend (Sakyi, Surkan, Fombonne, Chollet, \& Melchior, 2015). These findings suggest the critical importance of developing friendships early on in one's life.

Current policy and practice recommendations for schools and child care centers in Ontario reflect the importance of developing friendships at an early age. The Ontario Ministry Foundations for a Healthy School (2010) states that fostering a supportive social environment is an essential component of creating a healthy school. Furthermore, according to the new How Does Learning Happen? document, a pedagogical guide that is being implemented in child care centers across Ontario, 'belonging' is a foundational 
condition that children need in order to flourish in their environment (Ontario Ministry of Education, 2014). According to this document, belonging refers to "a sense of connectedness to others, an individual's experiences of being valued, of forming relationships with others and making contributions as part of a group, a community, the natural world" (p. 7). Thus, educators are expected to promote positive social relationships to enhance feelings of belonging in the classroom.

Despite the importance placed on developing friendship at a young age, studies on friendship in children under the age of three are rare (Webster \& Carter, 2007). This may be due to the prominence of developmental theory in research with children, as according to developmental theory, friendship develops in children around age three (Meyer \& Ostrosky, 2014). Thus, the majority of studies on friendship include children above three years old, and very little research involves toddlers (Engdahl, 2012; Webster \& Carter, 2007). This belief is also reflected in policy and practice, as the Early Learning For Every Child Today document used for developing early childhood education curriculum in Ontario states that children begin 'making friends' between the ages of 2.5 and 6 (Ontario Ministry of Education, 2007).

Yet early childhood educators (ECEs) have been found to commonly refer to children as 'friends' before the age of three. Statements such as "we're all friends in this classroom" have and continue to be commonly used by ECEs (Burk, 1996). Controversy has arisen over the use of this term to describe all children. Burk (1996) raises the point that referring to children as a group of friends implies that all children are friends in the classroom. According to Burk (1996), "children are placed in a classroom together because they are all in the same grade and probably because they all live in the same part 
of town, not because they are all friends with each other" (p. 282). While this point is made regarding school-age children, these points are equally as important in early childhood education. For children who enter child care, early childhood educators manage children's first introductions to social life outside of the family, and thus play a critical role in promoting positive social interaction (Buysse, Goldman, \& Skinner, 2003).

To promote these positive social interactions, early childhood educators have implemented strategies to encourage friendship formation (Buysse et al., 2003). Recent literature has revealed that educators use a number of strategies to promote friendship as well as social competence, positive interactions, and inclusion in early childhood education settings (Brown, Odom, Li \& Zercher; Kontos, 1999). However, little research has evaluated possible connections between educators' perceptions and implemented strategies for promoting friendship in practice (Webster \& Carter, 2007). As developmental theory is widely implemented in ECE practice, and developmental theory suggests children begin making friends around age three, it may be important to explore how educator's perceptions of children's abilities to form friendship influence their promotion of friendship in an early childhood education setting.

This study sought to explore: 1) educators' perceptions about promoting friendship in their classroom, 2) educators' reported and observed strategies for promoting friendship in their classroom, and 3) links between educator's perceptions and strategies used to promote friendship. Educator's perceptions were explored using semistructured, 30-minute interviews with each of the five educators. Regarding educator's specific strategies, this study attempted to explore educator's use of the word 'friends' in the classroom, and the strategies they report and implement to promote friendship in 
practice. Educator's practice was explored through daily observations (one-hour sessions) over the course of five days. By exploring both educator's perceptions and strategies in practice, it was hoped that this study would provide insight into how educator's perceptions about friendship affect how or if they promote friendship in their classroom.

\section{Theoretical Framework}

This study sought to explore educator's perceptions and practices involving promoting friendship using two theoretical frameworks: new sociology of childhood and developmental theory. New sociology of childhood along with developmental theory were chosen as the theoretical framework for this study because, together, they offer a unique view of childhood that differs from how childhood has been traditionally conceptualized. By using both developmental theory and new sociology of theory, it was hoped that educator's perceptions of friendship and practices used to promote friendship could be explored in a way that both addresses children as developing individuals as well as focus on children's strengths and abilities. Using these theories together may be specifically useful when studying friendship in children under the age of three, as developmental theories have often proposed that children do not begin making friends until after this age (Hay, Payne \& Chadwick, 2004; Kerns, 2000). Researchers implementing new sociology of childhood theory have in contrast yielded rich information about how young toddlers make friends (Engdahl, 2012). Thus, this study sought to use both developmental theory and new sociology of childhood to explore how educators perceive and promote friendship. These theories are described in greater depth in this section. 
Developmental theory. Developmental theory has been the dominant theoretical framework used when studying friendship in young children (Tisdall, 2012).

Developmental theories offer important insight into how children grow and develop from infancy to old age (Davies, 2011). According to Davies (2011), "development is founded on the child's genetically influenced characteristics, unfolds according to maturational timetables, and moves forward through a series of tasks and challenges of increasing complexity" (p. 3). As the child interacts with her surrounding environment, brain development and learning occurs; a process called the "transactional model of development" (Davies, 2011).

Developmental theorists have broken down children's development into stages according to a combination of capabilities and age (Guralnick, Neville, Hammond, \& Connor, 2007). Each stage signifies a host of new abilities in a number of domains (e.g. cognition, social, and emotional domains). These stages can be developed through maturation as well as environmental demands, which will stimulate and shape development (Davies, 2011). These stages have been implemented into teacher training and pedagogical guidelines to inform ECE practice (Ontario Ministry of Education, 2007).

Developmental theory is a relevant theoretical framework to consult when studying how educators perceive and promote friendship because it is the theory that has informed most of what is taught about children in modern educator training. However, developmental theory has been criticized for viewing children from a perspective that views children as 'weak' and 'innocent' (James \& Prout, 1997). The new sociology of 
childhood is a theory that has attempted to combat the developmental view of childhood (Tisdall \& Punch, 2012).

New Sociology of Childhood. The new sociology of childhood surfaced in the mid-1980s "arguing for the social construction of childhood to be acknowledged and for the recognition of young people's agency and rights” (Tisdall \& Punch, 2012, p. 249). Followers of this theory argue that 'childhood' has been historically conceptualized as a time of weakness, innocence, and immaturity (Dahlberg, Moss, \& Pence, 2007). They argue that children have been regarded as 'weak' and 'innocent' beings who are often considered 'less-than' adults (i.e. they are less skilled, knowledgeable, and rational than adults) (Matthew, 2007; Tisdall \& Punch, 2012). Qvortup (1994) describes this construct as viewing children as human 'becomings' rather than human 'beings', with childhood being a preparatory phase defined by incompetence that is overcome by the time a person develops into an adult.

Supporters of this theory concede that while "the immaturity of children is a biological fact of life... the ways in which this immaturity is understood and made meaningful is a fact of culture" (James \& Prout, 1997, p. 32). Thus, this theory can be used in conjunction with developmental theory, but provides a new viewpoint on childhood. The new sociology of childhood challenges how childhood has been constructed and proposes to conceptualize children based on their ability to contribute to society (Matthew, 2007). This belief has been supported by research suggesting that children actively construct their own realities (Matthew, 2007). Children have been said to "not simply internalize society and culture, but also actively contribute to cultural production and change" (Corsaro \& Fingerson, 2003, p. 130). The new sociology of 
childhood emphasizes the importance of viewing children as active participants in society, thus referring to children as 'social actors' (Matthew, 2007).

The new sociology of childhood also recognizes the complex and interactive nature of childhood. Children are not only viewed as independent agents, but as agents who interact with, influence, and are influenced by their environment and those within it (James, 2004; James \& Prout, 1997). According to followers of the new sociology of childhood, children are continuously involved in shaping and reconstructing each other through the locally organised relations and practices of the social groups in which they participate (James \& Prout, 1997; Matthew, 2007). It is believed that without a focus on children's agency, there is a risk of underestimating the effect social situations and peer culture have on children's lives (Whaley \& Rubenstein, 1994).

\section{Literature Review}

This literature review will help explore the topic of friendship in young children by discussing recent articles that address friendship in children under the age of seven. This section will describe the literature on educator's perceptions, how friendship in young children has been studied, what has been revealed about the nature of friendship, what has been found to affect friendship development, and strategies that have been recommended to promote friendship.

\section{Educator's Perceptions}

Educator's beliefs have been explored in the literature, defined as "implicit assumptions about students, learning, classrooms, and the subject matter to be taught" (Kagan, 1992, p. 66). Studies on this topic often use a number of different terms to refer to educator's beliefs, including terms such as perceptions, attitudes, and opinions (Kagan, 
1992). Compared to perceptions, attitudes, and opinions, beliefs represent a larger system made up of a number of perceptions and assumptions (Kagan, 1992). According to Pajares (1992), "the beliefs teachers hold influence their perceptions and judgments, which, in turn, affect their behavior in the classroom" (p. 307). In this study, educator's perceptions will be explored rather than educator's beliefs. It is assumed here that the educator's larger belief systems cannot be fully understood in this pilot study, but rather attempt to provide a glimpse into educator's perceptions. While research on educator's beliefs and perceptions has primarily focused on school-age teachers, the findings from this literature have been applied to research with early childhood educators (LaraCinisomo et al., 2008). This section will explore the literature on educator's beliefs as well as the perceptions and assumptions that follow.

Researchers have argued that educator's perceptions affect their practice (Hallinan \& Smith, 1989; Kagan, 1992). The literature has supported this argument when looking at the affects of educator's perceptions on student's final grades (Takei, Johnson, $\&$ Clark, 1998). Takei et al. (1998) reported that educator's perceptions of student's behaviour affected the student's mark in class. Research has also suggested that educator's beliefs are associated with compatible teaching styles that are consistently implemented across topics and grades (Evertson \& Weade, 1989; Kagan, 1992). For example, teachers who had cognitively-based perceptions of mathematics used more word problems to test students (Peterson, Fennema, Carpenter \& Loef, 1989).

Kagan (1992) argued that educators must rely on four groups of knowledge when making decisions in the classroom: 1) the specifics involving children in the particular classroom, 2) the subject matter, 3) prior experience, and 4) related perceptions, 
assumptions and beliefs. Pre-service teachers have been found to acquire most of their perceptions about practice based on practicum rather than course work (Zahorik, 1987). Then, when teachers enter the workforce, they have been found to make decisions largely based on their beliefs (Ashton \& Webb, 1986). Even when educators are provided with new textual or non-experience related information, as Kagan (1992) describes, "they filter it through their own belief systems, translating and absorbing it into their unique pedagogies" (p. 75). Educator's beliefs have been found to be relatively stable over time (Pajares, 1992). As educators gain more experience, their experience informs their beliefs, which according to Kagan (1992) develops into "a highly personalized pedagogy which will constrain their perception, judgement, and behaviour" (p. 76). Thus is appears that educator's beliefs and perceptions are fundamental to their decisions within the classroom. $\mathrm{x}$

Looking at educator's perceptions of friendship in the classroom, research has suggested that teachers rely on their perceptions to make subsequent decisions in the classroom (Pittinsky \& Carolan, 2008). In a study that evaluated the level of agreement between educator's perceptions of shared friendship between children in the classroom and children's reported friendship in the classroom, Pittinsky and Carolan (2008) reported that educators significantly under interpreted student friendships. According to Pittinsky and Carolan (2008), "there is reason to challenge the conventional notion that teachers' perceptions of within-class social relations are accurate" (p. 145). Pittinsky and Carolan (2008) argue that educators may be making classroom decisions based on inaccurate perceptions of friendship within the classroom. 
Studying the perceptions of educators is not a simple or straightforward task (Kagan, 1992). One cannot simply ask educators about their perceptions because their perceptions are tacit in nature (Kagan, 1992). For example, an educator may think she perceives mathematics in the same way as her colleagues, without being aware of how her perceptions differ from other educators. Educator's perceptions also cannot be inferred based on educator's practice, as practices may be implemented for a variety of reasons (Pajares, 1992). Educators are often unaware of the perceptions they hold, and lack the specific language that could be used to explore their perceptions (Pajares, 1992). Thus, educator's perceptions are often explored indirectly, based on their expressed perspectives on a topic through interviews (Pajares, 1992).

\section{Studying Friendship: Theories and Research Methods}

Friendship in young children has been predominantly studied from a developmental psychology perspective (Tisdall, 2012). Developmental theory was popularized by its ability to provide empirical support for child-raising practices and to connect theory with practice (James \& Prout, 1997). However, developmental theory has been said to contribute to the traditional view of childhood as 'less-than adult' (James \& Prout, 1997). For example, the use of the word 'developmental' in itself has been criticized due to its inherent connotation that children are in a constant state of growth from immaturity to maturity (James \& Prout, 1997). Advocates of the new sociology of childhood argue that these conceptualizations of childhood are inadequate for studying children on their own because this theory fails to address children's competencies and agency (Matthew, 2007). 
Applying developmental stages to children without considering their competencies may have negative consequential outcomes for research. As previously stated, children are thought to develop friendships around age three (Hay, Payne \& Chadwick, 2004). Thus, researchers who solely use developmental theory may limit their investigations only to children who are thought to have reached this developmental stage. For example, Kerns (2000) stated that children between the ages three and four were included in her study because "this is when children begin to form friendships" (Kerns, 2000, p. 313). In contrast, studies that used the new sociology of childhood to explore friendship studied how two-year-olds make friends and yielded rich, important data on friendship in young children (Engdahl, 2012). Thus, the new sociology of childhood in addition to developmental theory was chosen for this study to ensure that friendship is being studied in a way that recognizes children's strengths and abilities, as well as the developmental progression of friendship (which will be further discussed in the section on 'Making Friends'). It is hoped that by using the new sociology of childhood we will uncover new information about friendship in young children.

Relative to the number of studies conducted on friendship in older children (Fink, Begeer, Peterson, Slaughter, \& Rosnay, 2015), or on young children's non-peer relationships such as mother-child relationships (Engdahl, 2012), there have been few studies on friendship in very young children (van Hoogdalem et al., 2013). Barron (2011) suggests that this may be due to the influence of Jean Piaget's work, which regarded young children as "egocentric and their friendships as unstable, and, therefore, seemingly unworthy of study" (Barron, 2011, p. 658). Based on Piaget's theory, friendship has been viewed as a development stage that depends on children's ability to have 'theory of mind' 
or understanding of perspective-taking, which do not develop until children are around age three (Hay et al., 2004). As research using developmental theory is the dominant form of research with children, research on friendship in children has tended to only include children over the age of three.

Teacher, parent, or child reports have typically informed the occurrence of friendship in young children (Engle et al., 2011; Gleason \& Hohmann, 2006). These methods tend to be used in studies that implement a developmental theory. Parent and teacher reporting often involved adults filling out questionnaires that rate the prevalence and nature of friendships (Engle et al., 2011; Gleason \& Hohmann, 2006). These studies assume that adults are knowledgeable about the friendships between children and can accurately track friendships as they occur without testing for accuracy. Child reporting of friendship often involves questionnaires in a technique called 'peer-nominations', where children nominate who their friends and best friends are (Gleason et al., 2005; Gleason \& Hohmann, 2006; Hoyte et al., 2014; Laghi et al., 2014; Vu \& Locke, 2014). This technique often involves a ranking scale or pictures of friends (van Hoogdalem et al., 2013). The reliability of this method has been questioned as young children have been found to be confused by questions that differentiate friends from non-friends, with some children who "called all their children their friends" (van Hoogdalem et al., 2013). These researchers suggest that not all young children have the language to discuss friendship outright, and suggest using observational methods to explore friendship in young children (van Hoogdalem et al., 2013).

Less frequently, friendship was studied using observational methods. Two recent studies observed children under the age of three to explore friendship in young children 
(Engdahl, 2012; van Hoogdalem et al., 2013). Engdahl (2012) explored how children 'do friendship' by observing six one-year-olds through phenomenological methods as a participant observer. This study employed a new sociology of childhood perspective and yielded accounts of how these children made and maintained friendship. Van Hoogdalem et al. (2013) sought to measure friendship by observing 674 pairs of children and conducting factor analysis. The analysis revealed findings indicating behavioural characteristics of friendship in children aged two to three. The results of these studies will be included in the 'making friends' section below.

\section{Defining Friendship in the Literature}

Defining the construct of friendship in young children has gained attention over the last 20 years (Barron, 2011; Dunn \& Cutting, 1999). Friendship in young children has been defined as a bond between two children characterized by mutual preference, mutual affection, and engagement during interaction (Fink et al., 2015; Howes, 1983).

Definitions of friendship in young children also tend to refer to the importance of sharing emotions, both positive and negative (Engdahl, 2012). Additionally, friendship in young children has been described as characterized by two children who choose to play with each other and enjoy their playtime together (Howes, 1983).

Friendship has been distinguished from other social relationships based on reciprocal fondness and free choice (Fink et al., 2015). In most studies on friendship in children, both children in a friendship must regard the other as special (Fink et al., 2015). In the cases that one child may identify a second child as their friend but the second child does not reciprocate, researchers label this as a 'non-reciprocated' friendship (Laghi et al., 2014). A non-reciprocated friendship is considered a lower quality peer interaction 
than a reciprocated friendship, due to the lower level of mutual commitment between the children (Laghi et al., 2014). The reciprocal element of friendship has been said to ensure the relationship is equal and enjoyable for both children, and contributes to the maintenance of this friendship over time (Laghi et al., 2014). However, the benefits of friendship have been found to not be confined to reciprocal friendships. Non-reciprocal friendships have been found to be common among children with disabilities (Meyer \& Ostrosky, 2014). Furthermore, research has found that children with disabilities benefit psychologically from having non-reciprocal friendships (Webster \& Carter, 2007). Thus it appears that friendship is a complex phenomenon that comes in many forms, and has holds unique meaning across individuals.

The concept of familiarity has also been found to be important when looking at friendship. Researchers have identified familiarity as one of the key avenues to building a friendship (Engdahl, 2012; Newcomb \& Bagwell, 1995). Newcomb (1995) states that the difference between friends, non-reciprocated friends, acquaintances, disliked peers, and strangers is the level of familiarity ('knowing') and 'liking'. In other words, how a relationship is classified will depend on how familiar a child is with another child, and how much they like them. Children will label as 'friends' those who they like and know well. Similarly, they may label someone they know well but only moderately like as a non-reciprocal friend, and someone they do not know and might moderately like them depending on their initial interaction as a stranger (Newcomb \& Bagwell, 1995).

Whether or not researchers observe friendship in young children has depended on how the researchers define friendships. While definitions relying on verbal communications of preference for a friend have indicated that friendship begins in older 
ages (Hay et al., 2004), definitions that rely more heavily on actions than verbalizations have reported friendships in children's first years of life (Howes, 1983). Howes (1983) found that when friendship was defined based on behaviours (mutual preference, and enjoyment, as well as skillful interaction), infants, toddlers and preschoolers demonstrated reciprocal friendship. Friendship was interpreted based on dyadic interactions in infants through object exchange, in toddlers through a combination of object exchange and verbal communication, and in preschoolers through verbal communication (Howes, 1983). This article, authored by Carolee Howes, is a critical study of the exploration of the topic of friendship in young children and was therefore necessary for inclusion. The article was published in the journal of Child Development and has been referenced in the majority of current articles regarding how friendship in young children is understood. Howe's emphasized that friendship should be defined for each age group based on observations of the child's method of communication.

Two large-scale studies have evaluated the characteristics of friendships in children from various age groups to explore whether statistical differences can be found. In a meta-analysis of friendship relations in children ranging from preschool to adolescence, Newcomb and Bagwell (1995) found that friendships were characterized by "more intense social activity, more frequent conflict resolution, and more effective task performance" (p. 306). They found that school-aged children had more instances of 'positive engagement' than preschool aged children, thus indicating that preschooler's friendships may include more conflict than school-aged children. In a factor-analysis of friendships in children aged two to three, Van Hoogdalem (2013) characterized friendship differently than Newcomb and Bagwell (1995). Friendship in this younger 
group was characterized by playing together, prosocial behaviour, initiating activities and imitation (van Hoogdalem et al., 2013). Based on these findings, it is apparent that friendship differs according to age group.

\section{Studying Friendship: Making Friends}

An important question to explore when analyzing how educators promote friendship is how children form friendships. Many researchers have set out to determine the early roots of friendship (Engdahl, 2012; Fink et al., 2015). In the previous section, it was suggested that for friendship to be explored in younger children, it must be defined based on how the children indicate preference. This has been found to be achieved through observational methods (to observe behaviours) rather than reporting methods (as children may not be fully verbal). Thus, this section will explore how children have been observed 'making friends' at each age group according to the literature.

It is widely regarded that at birth, infants do not have the capacity to form relationships with other infants (Laursen \& Hartup, 2002). As children approach their first year of age, children's capacity to interact with other infants in a way that is deemed 'friendship' is questioned (Howes, 1983; Kerns, 2000). While many developmental theorists argue that friendship cannot be developed until later in life, Howes (1983) argues that infants can develop and maintain friendships if friendship is defined behaviourally. In an empirical study including 21 dyads of infants with an average age of 10 months, Howes (1983) reported that $14 \%$ of infants created and maintained friendship over the course of a year. A 'friendship' was observed when children expressed "mutual preference, mutual enjoyment, and the ability to engage in skillful interaction" (Howes, 
1983, p. 1042). The infants expressed their preference, enjoyment and skillful interaction through object exchanges, which increased in complexity over time.

Moving into the toddler years, it has been found that children in this age group use their bodies to make and maintain friendships (Engdahl, 2012; Howes, 1983; Whaley \& Rubenstein, 1994). While Howes's (1983) empirical study only described how toddlers' friendships differ from infant and preschool friendships (toddlers used less object exchange than infants, and less vocalizations than preschoolers), a recent study used phenomenological methods to explore how six young toddlers (aged $14-24$ months) created friendship. Over the course of nine months, toddlers created friendship through greeting each other, inviting another to play, and/or helping each other. The toddlers communicated their interest by eagerly looking at their peer to examine their facial expressions and gestures, and by using their own facial expressions and bodily movements to convey what they wanted to do (Engdahl, 2012). Young toddlers' use of their bodies to create friendship is continued into the later stages of toddlerhood, as toddlers (aged 22 to 32 months) were found to communicate affection by imitating another's actions (Whaley \& Rubenstein, 1994). The author suggested that this imitation serves to "non-verbally create similarity within a friendship" (Whaley \& Rubenstein, 1994, p. 398).

As we move into the preschool years, children begin to vocalize more frequently with their friends (Howes, 1983). However, the use of objects, bodily gestures, and imitation are still witnessed between friends (Howes, 1983). Children aged two to three who were deemed 'friends' were more likely to play together (including parallel play), 
engage in social interaction (including smiling and talking), imitate one-another, invite the friend to play, share, and show affection to their friend (van Hoogdalem et al., 2013).

In the kindergarten years, research on friendship begins to focus on how friendship is maintained. In five year olds, friendship was maintained by talking to friends, playing together, and storytelling (Howes, 1983; Hoyte, Torr, \& Degotardi, 2014). It appears that children's friendships become more verbal as children develop the abilities to express themselves verbally rather than with their bodies.

Research has emphasized that children must have the opportunity and time to build friendships. Children need time to become familiar with other children and need opportunities to determine the degree in which they 'like' the other child (Newcomb \& Bagwell, 1995). Niffenneggar (1998) proposes that whether children remain friends is largely based on opportunities to remain friends. Thus, if a child is moved to a new classroom where he/she does not know anyone, that child will need to take time to become familiar with her surroundings before friendships can be made. The more times this setting is changed, the more the child will have to 'start over' in making new friendships. Even if children are not moved between classrooms, within a classroom children must be given the opportunity to express their interest in other children (Niffenegger \& Willer, 1998). It has been frequently observed that children build friendships during the context of play (Hoyte et al., 2014). Niffenegger \& Willer (1998) recommends that educators and parents enhance children's opportunities for play through providing space and time for children to develop friendships.

Empirical research has found that there are predictors related to who children choose as friends. Children have been found to choose friends who are similar to 
themselves. Gleason (2005) reported that reciprocal friendships have been found most commonly between children who are more similar in preferences and appearances (e.g. activity preferences, sex, race). This phenomenon is referred to as the 'similarity attraction hypothesis' (Stone et al., 2013). This finding has been found to be relevant in practice, as educator's can manipulate similarities between children in order to facilitate friendship. For example, a study revealed that children who were playing with similar toys spent more time playing together (Fawcett \& Markson, 2010). Thus, providing children with similar toys may facilitate peer interaction (Fawcett \& Markson, 2010).

\section{Studying Friendship: Prevalence}

The prevalence of friendship in different samples of age groups have been reported in the literature. I will report the prevalence that has been observed by age, and then compare the prevalence of friendship as observed to those collected through nonobservational methods. The study conducted by Howes (1983) revealed that friendship in infancy and toddlerhood is more infrequent than in preschool-aged children, but more stable over time. Howes (1983) reported that out of 21 infant dyads, 3 friendships were witnessed, but all three remained stable over a year. In toddlers, out of 22 dyads, 10 friendships were witnessed, 6 of which remained stable over a year. In preschoolers, out of 36 dyads, 12 friendships were witnessed, with only 2 friendships remaining stable over a year. In contrast, a study on preschoolers with a much larger sample size of 674 dyads, using similar observational methods as Howes (983), revealed that $43 \%$ of children engaged in friendship (van Hoogdalem et al., 2013).

The prevalence of friendship based on peer nominations and parent nomination appears to be much higher than through observations. In children aged three to five, $86 \%$ 
of children were found to have reciprocal friendships (two children rating each other as friends) (Gleason \& Hohmann, 2006). In six-year-old children, 73\% were found to have at least one reciprocal friend in the classroom (Laghi et al., 2014). Parent nominations were even higher, as $93 \%$ of mothers of kindergarten-aged children perceived reported their child had a reciprocal friend in the classroom (Engle et al., 2011). Same sex friendships were found to be more prevalent than opposite sex friendship: same sex friends were identified in $80 \%$ of friendships (Gleason et al., 2006), and opposite sex friends were identified in $23.5 \%$ of friendships (Gleason et al, 2005). However, in studies that have looked at sex preferences in toddler friendships, no differences were found between gender preferences in one year olds (Engdahl, 2012).

In terms of the prevalence of reciprocal friendships using peer-nomination methods, research has indicated that reciprocal friendships are less common than nonreciprocal friendships. Laghi (2014) found that more than one-third of children designated their "best friend" as someone who did not designate them as their best friend. Furthermore, Laghi (2014) found that while 73\% of six-year-old children had at least one reciprocal friendship, only $27 \%$ had two or more reciprocal friendships. It was also found that as children tended to start using the term 'best friend', they would reserve this term for very "special" people (Niffenegger \& Willer, 1998). Leenders (1996) found that children tended to use the term 'friend' loosely, but 'best friend' was reserved for particular children.

\section{Recommended Strategies to Promote Friendship}

The majority of studies that have explored strategies to promote friendship in the classroom have analyzed inclusive settings and have included children with disabilities 
(Brown, Odom, \& Conroy, 2001; Buysse, Goldman, \& Skinner, 2003; Hollingsworth \& Buysse, 2009; Salend, 1999). Inclusive classrooms have been viewed as the gold standard for ensuring quality care in early childcare education settings. Brown (2001) suggests that creating inclusive early childhood programs will serve in itself to promote peer interactions between young children. Nonetheless, the following studies report on strategies that have been used to promote friendship in young children.

Buysse et al. (2003) sought to examine strategies teachers reported using to support friendships among young children in inclusive early childhood classrooms. The researchers provided questionnaires to teachers with a list of possible strategies. The teachers were asked to describe which strategies were used for a single child, and to rate the amount they used each strategy for this child (Buysse et al., 2003). The teachers most frequently used the following strategies: providing sufficient free choice time, allowing children to form their own friendships, and commenting on the play between friends. Teachers used more 'active' strategies for supporting friendship when one or more children had special needs (Buysse et al., 2003).

Salend (1999) provided recommendations for promoting friendship in a classroom with children with disabilities. She suggests that teachers can help children with disabilities develop friendships in inclusive settings by singing songs about friendship, singing songs that require two or more children to do physical movements, ask students to draw pictures depicting friendship, ask children to work on group projects on the topic of friendship, teach students humorous songs, and have students make posters with the attributes of what makes a good friend (Salend, 1999). This author emphasizes the 
importance of teaching children about individual differences as well as the meaning of friendship as a foundation on which friendship can be built.

In a study on parent and teacher roles in promoting friendship in three to five year olds, Hollingsworth (2009) found that parents and teachers in an inclusive environment used a variety of strategies to promote friendship. These strategies included, 1) setting the tone for friendship development by establishing appropriate and expected behaviour towards friends, 2) arranging the social environment to provide children with opportunities to interact and engage in communication on the topic of friendship, and 3) facilitating play between children. This author found that parents often asked teachers about their children's friendships, but teachers rarely asked parents about their children's friendships (Hollingsworth, 2009).

\section{Methodology}

\section{Approach}

As this study aimed to analyze the perceptions of educators, this study was conducted using a qualitative approach. Qualitative research focuses on the perspectives and experiences of research participants (Creswell, 2014). When conducting a study qualitatively, the researcher's role is to interpret data and construct meaning (Creswell, 2014). Qualitative approaches focus on the perspectives of participants and "privileges their constructed realities when reporting social science research findings" (Wheeldon \& Faubert, 2009, p.69). This approach does not operate under the assumption that there is a single, objective meaning to be revealed, as is often assumed in empirical, positivist approaches (Basit, 2010). Rather, a qualitative approach is used to explore the social world as a subjective, socially constructed phenomenon (Basit, 2010). Thus, a qualitative 
approach was suitable for my research question because I wanted to explore the associated complexities and implications of educator's perceptions about friendship.

\section{Sample and Recruitment}

This study took place in an early learning center because childcare centers are an ideal setting for children to experiment with friendship. Childcare centers are commonly one of the first places children experience social life. Part of the early childhood educator's (ECE) role in these settings is to promote social and emotional development (Ontario Ministry of Education, 2007). According to the Early Learning for Every Child document, a lead guiding document for practice in early childhood settings in Ontario, ECEs are expected to facilitate children's development of social skills from the beginnings of social interest in toddlerhood, to 'making friends' in preschool and kindergarten (Ontario Ministry of Education, 2007). Children who enter the social environment of an early childcare setting are often not accustomed to other children their age, and their social skills are in the primary stages. Thus, this study was conducted within an ELC because the early childcare setting is an opportune setting to observe social relationships in young children; and this study is being conducted with ECEs because they are in an opportune position to teach children the fundamentals of appropriate social behaviour.

The study was conducted in a single ELC with classrooms ranging from toddler to kindergarten. I aimed to recruit educators who taught in each classroom to explore how educator's beliefs and practices may differ across classrooms. As I was conducting both interviews and observations, I deduced that having five educators would provide robust and rich data for this study. I successfully recruited five ECEs from three different 
classrooms. Two of the classrooms had mixed age groups in them; a toddler/preschool room, and a preschool/kindergarten room, and the third room was a preschool room. For clarity, the toddler/preschool room will henceforth be called the toddler room, and the preschool/kindergarten room will be called the kindergarten room. The five participants have been provided with the following pseudonyms: Maddy, Darya, Audrey, Evelyn, and Talia. Each participant was a registered early childhood educator who worked full time at the ELC. Maddy and Darya worked in the toddler room, Audrey worked in the preschool room, and Evelyn and Talia worked in the kindergarten room. The range in age of children in each participant's classroom is described in Table 1.

The demographics of early childhood educators were not deemed of crucial importance to this study, but their years of experience and gender will be noted here. The participants ranged in the number of years they have practiced as early childhood educators. Darya and Audrey stated that they had practiced early childhood education for over 10 years, while Maddy, Evelyn, and Talia have practiced ECE for less than five years. Of the five participants, four were female and one was male. However, I will refer to all of the educators as female throughout the study. Although gender is an important variable in friendship, I think it important to

My process of recruiting educators consisted of meeting potential participants one-on-one with the assistance of the ELC manager. The manager introduced me to staff on two separate occasions to provide me with the opportunity to introduce myself and physically deliver recruitment forms to ECEs. The recruitment letter included information on my study as well as my contact information. Some participants discussed 
their interest in participating upon meeting me, while others emailed me over the course of the following week.

Once interest in participation was expressed, I sent an email to each participant with a copy of the consent form, which can be viewed in Appendix A. In my email, I informed the participants that the consent form were provided for their reference if time permitted. I informed them that we would be reviewing the consent form together before initiating the interview. The recruitment and consent form expressly stated that their participation included a 30-minute interview, the tape recording of this interview, and the consent for me to observe their classroom for five one-hour intervals. Interviews were conducted during work hours over the course of one week. Work study placement students were provided as supply staff during the half hour interview session.

During recruitment, I wanted to ensure that educators felt like valued contributors to my research project. Thus, I took precautions to ensure all participants were prepared and comfortable with each stage of the study. I provided the educators with sample interview questions prior to our interview. Some of the questions changed depending on the conversations as I conducted semi-structured interviews, but the sample questions I provided to the educators can be found in Appendix B. After the interview, I provided the educators with a copy of their transcripts for an opportunity for them to omit any sections they did not feel comfortable including in the study. Four of the five educators asked to see their transcripts, and none of the educators asked for any changes to be made.

\section{Setting}

The study was conducted in an early learning center. This setting was chosen because it was considered conducive to research due to the set up of the classrooms. All 
of the classrooms were equipped with one-way mirrors so I could unobtrusively observe the classrooms. Two of the classrooms also had microphones within the classroom and head sets so I could clearly hear what was being said within the classroom. Within both of these classrooms there were three microphones set up in different sections of the classroom. I could set my headsets to listen to any of the three microphones, depending on which section of the class I wanted to listen to. The third classroom did not have working microphones but did have one-way mirrors. This classroom also had better visuals as the one-way mirrors ran all the way along the classroom, while the other two classrooms had sections of the classroom that were more difficult to see.

In my study, I wanted to observe the naturalistic setting of the classroom in a way that was respectful to the children. This setting was conducive to my research because I was able to unobtrusively observe all children. While consent from all parents was attained when parents registered their children with the ELC, I decided not to seek assent from each child before conducting my study. I chose to do this because I believed it may make children act differently when they know they are being watched by an adult. While asking for assent would be been more conducive to the new sociology of childhood perspective, I decided to focus on observing the interactions between educators and children and optimizing a naturalistic observation environment. The ethical implications of not including children's assent in this study were considered. To minimize the impact this could have on the children, the identities of children were not recorded in field notes, and observations were limited to educator-child interactions. 


\section{Data Collection Process: Interviews and Observations}

This study used interviews and observations to explore the research questions at hand. Interviews were used to explore educator's perceptions of friendship and their reported strategies used to promote friendship in the classroom. Qualitative interviews "seek to foster learning about individual experiences and perspectives on a given set of issues" (DiCicco-Bloom \& Crabtree, 2006, p.314). Conducting interviews provided information on educator's perceptions of friendship in the classroom and their reported strategies for promoting friendship, however it did not provide direct information on their practice in its natural setting. Thus, observations were used to explore how educators promote friendship in practice. Observations are often used to explore the connections between participant's reported practices and their observed practices (Mulhall, 2003). These methods are discussed in more detail in the following sections.

Semi-structured interviews. The literature on interview methods has categorized interviews into three categories: unstructured, semi-structured, and structured interviews (Crabtree \& Miller, 1999). Structured interviews yield quantitative data, and thus only unstructured and semi-structured interviews are used in qualitative studies (DiCiccoBloom \& Crabtree, 2006). Semi-structured interviews were chosen as the method to explore educator's perceptions of friendship and reported strategies as this form of interview is commonly used to "delve deeply into social and personal matters" (DiCiccoBloom \& Crabtree, 2006, p. 315). The questions used in unstructured interviews are often developed after observations in ethnographic studies. As this study attempted to use observations to connect educator's reports and practices, it was determined that 
observations would be used after conducting observations rather than used to inform unstructured interviews.

I used interviews to ensure that my methods were conducive with a qualitative approach to exploring educator's perceptions using their own words. One thirty-minute, face-to-face interview was conducted with each educator. The questions used in semistructured interviews are not fixed; the researcher can alter questions as they learn about the participant (Johnson, 2002). Departing from the research questions based on the participant's interests is considered productive when using this approach as the goal is to provide a deeper understanding of the participant's perspective (Johnson, 2002). Furthermore, questions that are not particularly effective can be dropped and new questions added if necessary upon data collection (Johnson, 2002).

The interview was conducted face-to-face and was audio recorded. The face-toface element of the interview allowed for an easier avenue to develop rapport with the participants. Rapport is an important element to develop in interviews to promote a feeling of comfort and trust between the researcher and participant (DiCicco-Bloom \& Crabtree, 2006). Audio recording using a tape recorder was necessary for ensuring the interviews could later be properly transcribed (Johnson, 2002). Tape recorders are the most common form of recording for semi-structured interviews (DiCicco-Bloom \& Crabtree, 2006). Consent forms were signed prior to recording any of the interviews. Initial interview questions were provided to each educator before meeting via email. The interview was scheduled during work hours in a secluded area close to the participant's classroom. The interview began with questions regarding educator's perspectives of friendship in their classroom. Then, the questions focused on strategies 
used in their class to promote friendship. One educator had prepared answers to questions before meeting with me, and referred to a computer document when answering questions. Some questions were asked based on her interest that she had not prepared for, which she answered. The other educators appeared to have briefly looked at questions beforehand and did not prepare answers. The interviews were thirty minutes long so as to balance the amount of time educators were away from their class and the in-depth nature of the interview.

Naturalistic observations. The second method of data collection was implemented in this study to observe how educators use strategies to promote friendship in practice. Observational methods have been categorized into two categories in the literature: 1) structured observations, a form of observation often used in quantitative research that has predetermined characteristics which are checked off as they are observed, and 2) unstructured, naturalistic observations, a form of observation often used in qualitative research without a predetermined notion of what will be observed (Mulhall, 2003). This study used naturalistic, unstructured observations. While researchers using this method have a predetermined question or idea to explore, these questions may adapt as data is gathered (Mulhall, 2003). Observers may also range from participant observer, in which the researcher is placed in the setting of observation as a participant, to full observer, in which the researcher is a discreet observer who watches from the sidelines of the setting (Mullhall, 2003). This study adopted a discreet observer method in order to capture the naturalistic setting and minimize disruption of the classroom.

Field notes were made describing how educators appeared to promote friendship in practice, the number of times the word 'friends' was used in the classroom, and in 
what context the term 'friends' was used. It is important to note here that field notes are not viewed in this qualitative study as a reflection of the 'true' or 'actual' reality, but rather a constructed view of educator's practice based on the researcher's perceptions. This concept was recognized by Atkinson (1992) as "something we construct both through the practical transactions and activities of data collection and through the literary activities of writing field notes, analytic memoranda and the like" (p. 5). Thus, the data collected on educator's strategies and use of the term 'friends' in practice is regarded as an additional viewpoint on this topic, not the 'true' depiction of their practice.

Naturalistic observations were conducted using one-way mirrors in each classroom to observe the classroom. Five, one-hour long sessions of observation were conducted in each of the three classrooms for a total of 15 observations. During observations, I took notes of interactions between educators and children and any strategies that could be perceived as promoting friendship in the classroom. I observed the classrooms primarily during free playtime in the morning (between 11:00pm and 12:00pm) or in the afternoon (between 3:00pm and 4:00pm). It was often difficult to properly hear each aspect of an interaction as some of the microphones were broken in the ELC, at which point interpretations were made based on non-verbal cues.

During the observations I took notes by hand. I wrote down anything I felt was relevant at the time, including quotes, descriptions of actions, descriptions of children, staff, and context. I also wrote reflections as they came to me during the observation session. After the hour-long observation session had passed, I returned to my notes and wrote out any additional reflections I had about what I saw. I then typed these notes into a secure computer for analysis after the completion of my observations. When names were 
used in the classroom, I wrote them in my notes as " $\mathrm{X}$ " and " $\mathrm{Y}$ ", and later converted the letters to pseudonyms for ease of reading comprehension.

\section{Analysis}

I began my data analysis by transcribing the five interviews. The goal of transcription was to provide a verbatim written representation of the interviews to aid further analysis. Research on transcription processes has reported that there are challenges in creating a verbatim transcript, as transcription involves interpretation (Tilley \& Powick, 2002). For this study, I attempted to transcribe the interviews as accurately as possible, but I also recognized that the process inevitably involved my interpretations. Upon completing transcription of the interviews, the field notes from observations were re-written from their paper-and-pen form and were typed to ease reading comprehension. To familiarize myself with the depth and scope of the data, I immersed myself in the information from both the interview and observation notes by reading them multiple times, taking note of ideas and possible patterns as I read (Braun \& Clarke, 2006).

This data was analyzed using thematic analysis. Thematic analysis is "a method for identifying, analysing and reporting patterns themes within data" (Braun \& Clarke, 2006, p. 79). Thematic analysis differs from other qualitative analytic methods in that it does not seek patterns that are "theoretically bounded" (Braun \& Clarke, 2006, p. 80). I used an emergent approach to identify themes that related to the research questions at hand that were representations of the data, and my interpretations of the data (LeCompte, 2000). To find themes related to educator's perceptions of friendship and their reported strategies for promoting friendship, I analyzed the data from the participants' interviews. 
To provide themes related to educator's strategies for promoting friendship as observed in practice, the field notes were analyzed. Data from the interviews and observations were compared to provide themes on possible connections between educator's perceptions and their practice.

A thematic analysis approach similar to the approach described by Braun and Clarke (2006) was implemented in this study. After familiarizing myself with the data, I coded all of the data into initial codes. These codes reflected what appeared to be interesting and relevant to the research questions at hand (Braun \& Clarke, 2006). Two sets of initial codes were created: the interview data was analyzed for codes related to educator's perceptions and reported strategies, and the observation data was analyzed for codes related to educator's observed practice. To code the reported and observed strategies, codes were created based on frequency of report or observation. To assist in the organization and coding of the data, I coded the data using a computer-assisted qualitative analysis software (CAQDAS) called NVivo. Using CAQDAS has been said to "take qualitative data analysis much further than is possible compared to conducting the analysis manually" (Leech \& Onwuegbuzie, 2011, p. 71). This is because CAQDAS offers assistance with storing, coding, and indexing qualitative data. In qualitative research, the researcher is the interpreter of the data (Creswell, 2014). Thus, computerassisted qualitative data analysis software does not conduct an analysis of the data, but rather assists the researcher by providing an avenue to easily organize and code the information for the researcher to analyze.

Once all of the data was coded, the codes were organized into broader themes (Braun \& Clarke, 2006). Organizing the data into themes allowed for connections to be 
made within and between the initial codes, including connections between educator's perceptions and practice. I then reviewed the themes for connections between themes, evaluated the substance of the support for each theme, and refined the themes as needed. Finally, I defined and described each theme and discussed their broader implications (Braun \& Clarke, 2006). The resultant themes and implications can be found in the following section.

\section{Findings, Analysis and Discussion}

This section has been split into three sections: educator's perceptions about friendship, educator's reported strategies, and possible links between perceptions and strategies. Within each section, findings from interviews and observations will be discussed, as well as possible implications for research, practice, and policy. Finally, a summary of the findings is offered at the end of the results section. A breakdown of the participants, classrooms, and children's ages of each classroom can be found in Table 1.

\begin{tabular}{|c|c|c|}
\hline \multicolumn{3}{|c|}{$\begin{array}{l}\text { Table } 1 \\
\text { Classrooms, Participants, and Children's Ages }\end{array}$} \\
\hline Classroom & Participant & Children's Range in Age \\
\hline Toddler Room & $\begin{array}{l}\text { Maddy } \\
\text { Darya }\end{array}$ & 18 months -2.6 years old \\
\hline Preschool Room & Audrey & 2.5 years -3 years old \\
\hline Kindergarten room & $\begin{array}{l}\text { Evelyn } \\
\text { Talia }\end{array}$ & 3 years -7 years old \\
\hline
\end{tabular}

Table 1

\section{Educator's Perceptions}

This section will explore findings from educator's interviews. Educator's perceptions were analyzed based on their responses to questions regarding their thoughts about friendship in their classroom. This section will include educator's perceptions of 
using 'friends' to refer to children, friendship, and their role in promoting friendship in the classroom. In general terms, educator's did not agree with using the term 'friends' to refer to children in practice, except for a couple of educators who perceived the term acceptable to refer to the children as their friends. Educator's perceptions about friendship were plotted on a continuum ranging from new sociology of childhood to developmental theory. Not all educators perceived friendship as occurring in their classroom. While it may have been expected that educators in the toddler room did not perceive friendship to occur, this was not the case. Educators in the toddler room actually appeared to display perceptions that aligned with new sociology of childhood. They perceived friendship to occur in their classroom despite the children's age. However, one of the educators in the toddler room did not perceive it to be her role to promote friendship in the toddler room, nor did the educator in the preschool room. These perceptions appeared to reflect influence from developmental theory.

Using the term 'friends' to refer to children. When interviewing the educators on their perceptions of friendship in the classroom, educators were asked whether they used the term 'friends' to refer to children in the classroom. Educators reported that while they were generally opposed to using the term, and were aware of the controversy surrounding the term, and they found themselves using it out of habit. The educators were more comfortable with using the term to refer to children as their friends rather than a group of friends, as they did not want to assume that all of the children were friends. Educator's used the term more frequently in the toddler room than the kindergarten and preschool room. These findings are discussed in greater detail in the following sections. 
Perceptions about how 'friends' is used. Based on the interviews, educators appeared to use the term 'friends' to refer to children in two ways. The first was to refer to children as educator's friends, as in "my friends, come with me". Using the term this way, the emphasis was more on the children being the educator's friends than the group of children all being friends with one another. The second way 'friends' was used by educators was to refer to all the children as a group of friends, thus implying that all of the children are friends with each other. From here on, the former use of the word friends will be referred to as "educator's friends", and the latter will be referred to as "children's friends".

All of the participants stated that they had reservations regarding the use of the word 'friends' to refer to children. Each educator specified that they particularly did not agree with using the term to refer to children as "children's friends" because they do not want to make the assumption that all of the children are friends. Maddy summarized this sentiment when she said, 'ideologically I'm opposed to using the word 'friends' to call the group all friends, and using that kind of language of saying 'we're all friends here,' because we're not. It's not, even when you're two there's just people who you just don't connect with, you don't like them and that's okay". Talia similarly stated, "in the classroom, its clear that not everyone is friends with everyone. I don't want to make the assumption that these children are friends".

'Friends' as a controversial term. Additionally, the educators appeared to be aware of the controversy regarding the use of the word 'friends' in practice. Maddy said, "in early childhood it gets criticized a lot with people calling all the kids friends like “okay friends, it's time to go outside!' I've heard some practitioners say, 'It's not 
appropriate, we're not all friends, you don't have to be friends with everyone'”. Thus, when they said that they use the term 'friends' in practice they often described it as if they felt they were not supposed to use the term. For example Evelyn said that she “catches herself" calling children friends.

Children as educator's friends. While all of the educators were opposed to using the term 'friends' to refer to "children as friends", there were conflicting perceptions regarding the use of the term to refer to children as 'educator's friends'. These perceptions appeared to coincide with whether educators actually perceived children as being their friends or not. Evelyn, Talia, and Darya expressed that they do use the term to refer to children as their friends because they perceive it to be true. For example, Darya said, "To me I feel all of them are my friends", and Talia says, "when I'm talking to all of the children that is often when I say friends. But when ... a situation happens, hitting for example, I'm like do you hit someone else? Because I think that's not just for friends". Evelyn expressed that while she felt she was friends with some of the children, she was not friends with all of them. She said, "I have to think about it sometimes because not all of us are friends". Audrey stated that educators are being disingenuous when they call children their friends. She said when student teachers use the term in her class, she asks them, "do you have dinner with them? Do you go to the movies with them?' And they say no, and I say, 'they're not your friends. They're your acquaintances'. And they're like 'I know, I know but it sounds nice!'. I say, 'it sounds nice, but its not really a truth is it'”. Although the educators generally held negative perceptions about using the term 'friends' to refer to children as "children's friends", two of the five educators reported accidentally using the term to refer to children as friends with each other. Responses to 
the interviews indicated that educators used this term out of habit and because there are was a lack of alternative appropriate group terms. Maddy and Talia stated that they tend to use the word 'friends' in their practice out of habit. Talia said the term was used when she was first learning to be an early childhood educator. She said, "a lot of its been picked up just because ... I was developing and learning for myself how to be an educator so I picked up things here and there". Further, Maddy and Talia expressed difficulty in finding an appropriate term to refer to children. Both state that 'children' emphasizes a difference in power between educator and child and 'boys and girls' is a restrictive term in regards to gender variations. For example, Talia stated "I never wanted to separate having that authoritative role where its like okay I'm the ECE, you're a child". Thus, it appeared that educators used this term out of habit, or resorted to using this term due to a lack of appropriate alternatives.

Educator's perceptions of friendship in the classroom. Educator's perceptions were placed on a continuum ranging from new sociology of childhood (where educators had high expectations of children regardless of their age) to developmental theory (where educators prefaced their perceptions about their expectations based on children's age). Not all educators appeared to be confident that friendship regularly occurred in their classroom. In opposition to developmental theory, both educators in the toddler room (with children under age three) perceived that friendship regularly occurred in their classroom. Educators who were not comfortable using the term 'friendship' to describe children's relationships in the classroom appeared to hold more sophisticated definitions of friendship than the other educators. While all of the educators perceived it to be their role to promote friendliness in the classroom, only Darya and the two kindergarten ECEs 
described promoting friendship as part of their role. These findings are described in more detail in the following sections.

Continuum of educator's perceptions. After reviewing the data from the participant's interviews, a pattern emerged regarding how educator's perceived children's friendships in the classroom. It appeared that educator's perceptions could be plotted on a continuum ranging from what I have termed 'new sociology of childhood' to 'developmental theory' (Figure 1).

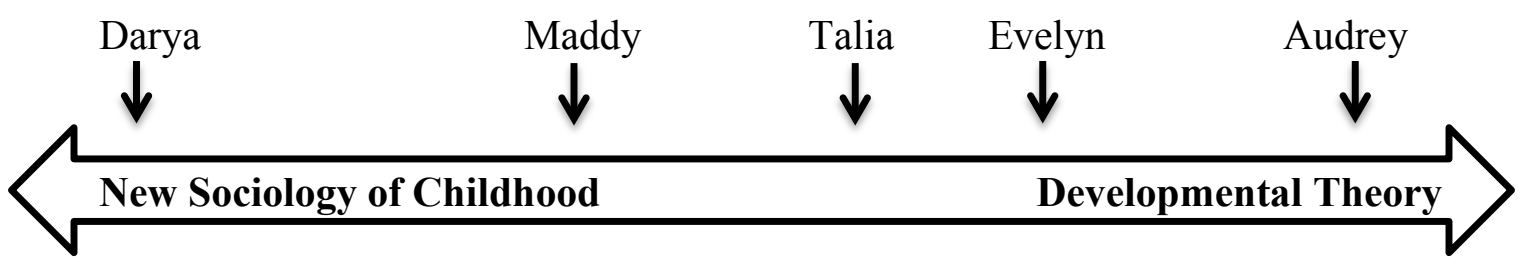

Figure 1. Continuum of educator's perceptions from New Sociology of Childhood to Developmental Theory. This figure illustrates where educator's fall on a continuum of possible perceptions about friendship in young children.

Educator's perceptions appeared to reflect notions both from new sociology of childhood (NSC), which emphasized viewing children from a strength-based perspective, and developmental theory, which emphasizes the effect of children's age or developmental stage on children's abilities. For example, Darya aligned strongly with NSC. She stated in her interview, "I have a tendency not to underestimate, and have high expectations of children because I believe that when you believe in them, and you expect something from them, they will actually be able to do it then”. In contrast, Audrey appeared to align more strongly with developmental theory than new sociology of childhood. For example, when asked about the occurrence of friendship in her class, she stated "[friendship] is more of a developed idea for this age, for what they do, because 
they're very egocentric". Thus, it appeared that Darya perceived children's abilities to be dependent on her own expectations of them, a belief consistent with that proposed by NSC, while Audrey perceived children's abilities to be dependent on their age, based on findings from extensive research on children's development. In this study, it is not assumed that any theory is more appropriate than another, but rather that it may be helpful to explore these perceptions more in depth, and how they relate to perceptions about friendship and the promotion of friendship in the classroom.

Perceptions of friendship occurrence. Educators shared in their interviews whether they perceived friendship to occur in their respective classroom. All educators described relationships that could be construed as friendship in their classroom, but only three of the five educators confidently asserted that friendship regularly occurred. The other two educators (Audrey and Talia) were resistant to calling the relationships between children 'friendships', but rather described the relationships as the first stages of a friendship or as a school-based relationship, such as an acquaintance.

Describing the occurrence of friendship. Both educators in the toddler room perceived friendship to occur in their classroom. Darya provided an example of friendship. During her interview, she said, "we had a few children, very young, one in particular comes to mind, when they were not even two yet, the two girls were constantly together. To me that was friendship". Similarly, both educators in the kindergarten room perceived friendship to occur in their classroom. Evelyn described it as a "connection" between children. She said, "they do connect, some of them do find connections between each other". 
Resistance to referring to child relationships as 'friendship'. Talia and Audrey were both resistant to using the term 'friendship' to refer to children's relationships. Talia said,

So for young children, they're view of friendship or when they call someone their friend is I guess like the beginning stages... in the classroom a lot of children do actively seek each other out to play. Yes, there's a lot of conflict that does happen in the classroom but, I think that in terms of friendship...there's a lot of partnership in terms of what they do but I wouldn't say that these children are friends, its not for me to judge. But, when I do see them in the classroom I see okay these two have a relationship, building whatever it may be.

Similarly, Audrey from the preschool room had reservations about using the term 'friendship' to refer to children's relationships. She said, “I wouldn't really call it friendship in the classroom ... I'd call them like their peers, acquaintances... some children we do say they create a bond... if their families spend time together, then there's a friendship that develops". Thus, it appeared that Audrey reserved labeling friendship to children who spent time together outside of school.

Referring back to developmental theory, it may be relevant to discuss when children begin making friends according to developmental theory. As previously discussed, developmental theory suggests that children begin forming friendships around the age of three (Kerns, 2000). This theory has been supported by the Early Learning for Every Child Today document used as a guide ECE practice in Ontario, whereby educators are recommended to begin supporting children in the process of 'making friends' when children are between 2.5 and 6 six years old (Ontario Ministry of 
Education, 2007). Thus, it is interesting to note that both educators in the toddler room reported that friendship occurs in their classroom. This finding indicates that the educators rely less heavily on developmental theory to inform their perceptions about the occurrence of friendship in their classroom. It also supports Audrey and Talia's perspectives in the preschool and kindergarten room, as they believed friendship to be rare or at the beginning stages. These perceptions are consistent with developmental theory, and may indicate that these educators rely on developmental theory to inform their practice and perceptions.

Educator's definitions of friendship. Educator's perceptions about the occurrence of friendship in their classroom appeared to be dependent on how friendship was conceptualized by educators. The three educators (Darya, Maddy and Evelyn) who defined friendship based on time spent together and similar interests also believed that friendship occurred in their classroom, while the two educators (Audrey and Talia) who defined friendship based on sharing thoughts and supporting one another were resistant to applying the term friendship to describe relationships in their classroom. These findings are discussed further below.

Sophisticated definitions of friendships. The educator's who were resistant to applying the term friendship to describe children's relationships in their classroom appeared to define friendship in more sophisticated terms than the educators who were more confident about the occurrence of friendship in their classroom. For example, Talia described friendship as "two individuals working together, caring about each other, sharing materials, expressing thoughts with each other". Similarly, Audrey described a friend in the following way: 
Someone who is there for you, supports you...you get along with you have fun with and share things with, things like that. So when I look at this age, they're still learning a lot about themselves, about interactions, so I look at that as more of a working friendship. Or seeking friendship.

Classroom-specific definitions of friendship. In comparison, Darya, Maddy and Evelyn described friendship more specifically to what they observed as friendship in their classroom. For example, Evelyn said, "they would start finding similar activities together and be with each other a lot. Thats sort of the friendship that we've noticed in the room". Similarly, Darya described friendship in her classroom as "not necessarily just hanging out together like what we see as adults, but its learning how to be around others. So slowly developing those friendships. Figuring out what it actually means".

After analyzing the definitions of friendship provided by the participants, it appeared that educator's definitions of friendship influenced whether they perceived children's relationships as friendship in the classroom. Referring to the literature on defining friendship, Audrey and Talia's sophisticated definitions of friendship appeared to align with definitions of friendship in adolescence or adulthood. Berndt (2002) defines friendship in adolescents and adulthood as characterized by intimacy, emotional support, self-disclosure, affection and reliability. Audrey's focus on someone who is "there for you" and Talia's mention of "expressing thoughts" appears to align well with friendships in adolescent and adulthood. In contrast, friendship in young children has been conceptualized as relying on mutual preference, affection, and engagement during interaction, often involving spending time playing together (Howes, 1983). Darya, Maddy and Evelyn's descriptions of friendship appear to align more with how friendship 
has been defined for young children. This may account for why Audrey and Talia were less confident about friendship occurring in their classroom.

Educator's perceived role in promoting friendship. The participants were asked about their perceived role in promoting friendship in the classroom. The educators appeared to be split between two perceptions of their role: promoting friendship, and promoting friendliness. While it may have been presumed that educators who perceived friendship as occurring in their class would perceive part of their role as promoting friendship, and that educators who were resistant to using the term friendship perceive their role as promoting friendliness, this was not the case for two of the five educators. Although Maddy perceived that friendship occurred in her classroom, she perceived it to occur naturally, without her interaction. Likewise, although Talia was resistant to using the term 'friendship' to describe relationships in her classroom, she perceived promoting friendship to be an important part of her role as an ECE.

Role in promoting friendship. Darya, Evelyn, and Talia reported that they thought promoting friendship was part of their role as an ECE. Darya said, "I see my role to help [the children] develop those skills, those abilities, understanding of how to be with other kids ... how to have friendships". Evelyn said that she often asks her self in practice, "how can we work with them to help them with their friendship and help them build on it?" Talia similarly stated,

I do think that it is part of my role, because friendship I think has a lot to do with social and emotional development...that's part of what we do, that's part of our practice. We try to give children the experience or opportunities to develop social 
skills and emotional skills because its again, from how I define friendship, its almost fundamental in creating a bond.

Thus, it appears that only the educator who strongly aligned with NSC and the two kindergarten educators perceived promoting friendship as part of their role. This may reflect an influence of developmental theory confining the promotion of friendship in young children. As Evelyn and Talia work with children who are well within the 'making friends' stage of development, promoting friendship may be expected of them. However, the same cannot be said in the toddler and preschool room. Darya appeared to perceive promoting friendship to be her role due to the high expectations she holds for the toddlers in her room. This finding may support an argument for introducing NSC theory to educators to promote a strength-based lens when working with young children.

Role in promoting 'friendliness'. Rather than believing their role was to promote friendship, two educators indicated their role was to promote 'friendliness' in the classroom. While all educators expressed the importance of maintaining friendliness in the classroom as well as friendship, Maddy and Audrey emphasized this as what they focus on rather than individual friendships. Maddy stated, "I would look at my role more as promoting friendliness and respect than promoting specific kids' play together". Audrey also described the importance of maintaining a friendly environment. When asked about her role in promoting positive interactions (as she was resistant to the term 'friendship), she stated, "you're going to get children who are constantly clashing and you have to figure out how to get them to be beside one another because we as adults have to do the same thing". 
It is important to note that while all educators described the importance of maintaining a positive environment in the classroom, Audrey and Maddy described this as their focus, and did not identify promoting friendship as part of their role. In an example of an emphasis of both concepts, Evelyn in the kindergarten room said, "we don't push children to be friends with certain people because not everyone is friends with each other... with the children we teach them to be respectful. Even if they're not friends, they should be respectful to each other because we're sharing the same space".

Educators perceptions that promoting friendship was not part of their role appeared to depend on one of two reasons: 1) whether educators perceived friendship occurred in their classroom, and 2) whether educators perceived children needed assistance when developing friendship. As previously described, Audrey agreed that her role was promoting "social relationships" rather than friendships because she did not feel 'friendship' was the correct classification for social relationships in her class. While Maddy did perceive that friendships existed in the class, she did not perceive promoting friendship was part of her role because she believed children develop friendships on their own. She says, "I find the friendships, like the preferred playmate aspect of friendship seems to just happen. Without my intervention and sometimes I find it really mystifying like who the kids connect with like that I wouldn't expect". This perception may reflect an influence of developmental theory, as implemented in the Ontario Early Learning for Every Child Today document (Ontario Ministry of Education, 2007)

\section{Educator's Strategies}

Based on the strategies reported by educators and observed in practice in this study, I have categorized educator's strategies for promoting friendship into three broad 
categories: active, reactive, and passive. Active strategies are categorized as being preplanned, organized activities acted out by the educators. Reactive strategies are categorized as responses to situations to promote friendship. They are not pre-planned like active strategies, but are rather enacted to resolve or facilitate an interaction between children. Passive strategies are characterized as indirectly promoting friendship or promoting through inaction (e.g. observing, modeling). A full description of each strategy reported can be found in Appendix D.

Observations of interactions between the participants and children were often difficult, as the ECEs tended to do less child interaction and more classroom-wide duties than early childhood assistants (who were not participants, and therefore not described here). The most frequently observed and reported strategies across all educators were reactive strategies, particularly facilitating interactions between children. The way in which interactions were facilitated appeared to differ by classroom, with a focus on communication in the toddler room, managing emotions in the preschool room, and problem solving in the kindergarten room. Educators in the preschool and kindergarten rooms appeared to implement more active strategies than the toddler room educators, while the toddler room educators appeared to implement more passive strategies. These findings are discussed further in the following sections.

Use of the term 'friends' in practice. During the observation sessions, notes were taken each time a participant used the term 'friend' to refer to children as “children's friends" or "educator's friends". It appeared that 'friends' was used often in the classroom, mostly referring to children as "educator's friends" and most often in the toddler room. A further description of these findings follows. 
Four of the five educators were observed using the term 'friends' in their classrooms. Audrey was the only educator to not be observed using the term 'friends' to refer to children in the classroom. Three of the educators (Darya, Evelyn and Talia) referred to children as "educator's friends". Each statement was prefaced with "my" before "friends" to indicate that they were calling the children their friends. For example, Talia was observed saying “So my friends, if you've finished tidying up, please come to the book area". One educator (Maddy) referred to children as "children's friends". She intervened with a child who hit another children and said, "we do not hit our friends". The use of the term 'friends' was most frequently observed by the educators in the toddler room, and least frequently observed by the educators in the kindergarten room. Thus it appeared that educators who taught younger children used the term 'friends' more frequently than educator's who taught older children.

From a new sociology of childhood perspective, it is not surprising that educators of young children are using the term 'friends' to refer to children. According to supporters of this theory, referring to all children as friends aligns with a perspective of 'the child as an innocent'. According to Dahlberg, Moss and Pence (2007), viewing children as innocent and weak, "generates in adults a desire to shelter children from the corrupt surrounding world" (p.45). In other words, younger children may be being sheltered from the reality that not all people get along. However calling all children friends may leave children with an unclear understanding of what the term 'friends' means. In a study by Van Hoogdalem (2013), reported that when children aged two to three were asked who their friends were, "they looked very puzzled and refused to do anything, or they called all the children their friends" (p. 237). The confusion about the 
term could be a reflection of the way the term 'friends' is often used in early childhood settings. It may be beneficial to use an alternative word to refer to groups of children.

Frequency of reported and observed strategies. Before discussing educator's perceptions and strategies, it is important to note a finding that affected the observations conducted within this study. This study intended on observing the participants interacting with children during the five observation sessions, however, it appeared that the participants did less interacting with the children than other staff. This may be due to the status of ECE versus early childhood assistant (ECA) status within the classroom. It appeared that the ECAs did more interacting with children during free play, while the ECE staff did more class organization, programming, and other classroom wide duties. This is an important finding in itself, as there has been discussion about how the roles of ECEs are perceived.

The code frequency for each reported strategy can be found in Figure 2. The most commonly coded strategy reported was reactive strategies (reported 9 times, followed by active strategies (reported 8 times), and passive strategies (reported 6 times).

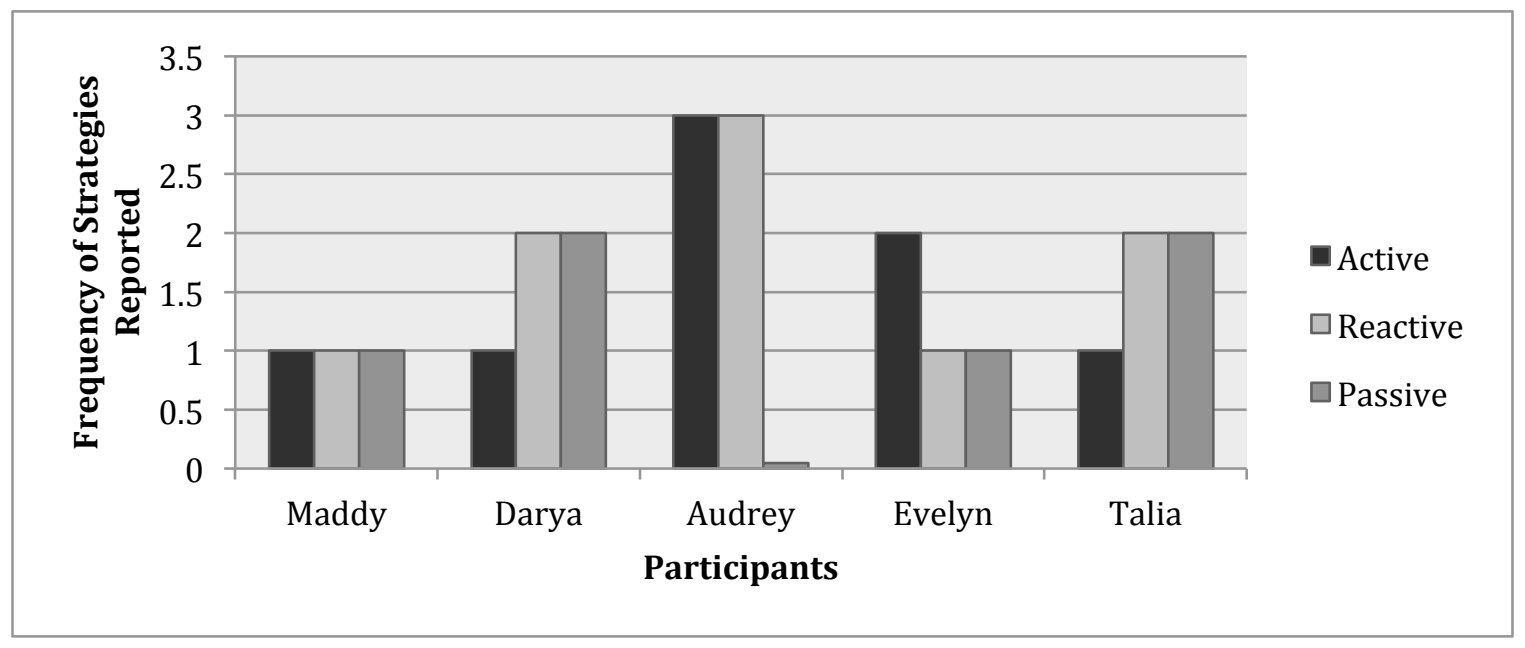

Figure 2. Educator's reported strategies. This figure illustrates the frequency of reported strategies by participant. 
The code frequency for each observed strategy in practice can be found in Figure 3. Reactive strategies were also the most observed strategy used (observed 22 times), followed by passive strategies (11 times), and active strategies (10 times). It should be acknowledged here that the observed strategies might not have provided a full representation of the strategies implemented by educators, as participants were only observed for one hour a day during free time and part of circle time. Free time is a time of the day where children have the option of playing freely, or joining in on a planned activity. As there would only be one scheduled activity per session, it is understandable that the number of observed active strategies is less than reactive strategies. Similarly, as passive strategies are subtle in nature and not always obvious to the observer, it is likely that many instances of passive strategies were missed during observations sessions. Furthermore, as was previously discussed, ECAs appeared to spend more time interacting directly with children than ECEs. The observed strategies are limited to the ECEs who consented to participation within this study.

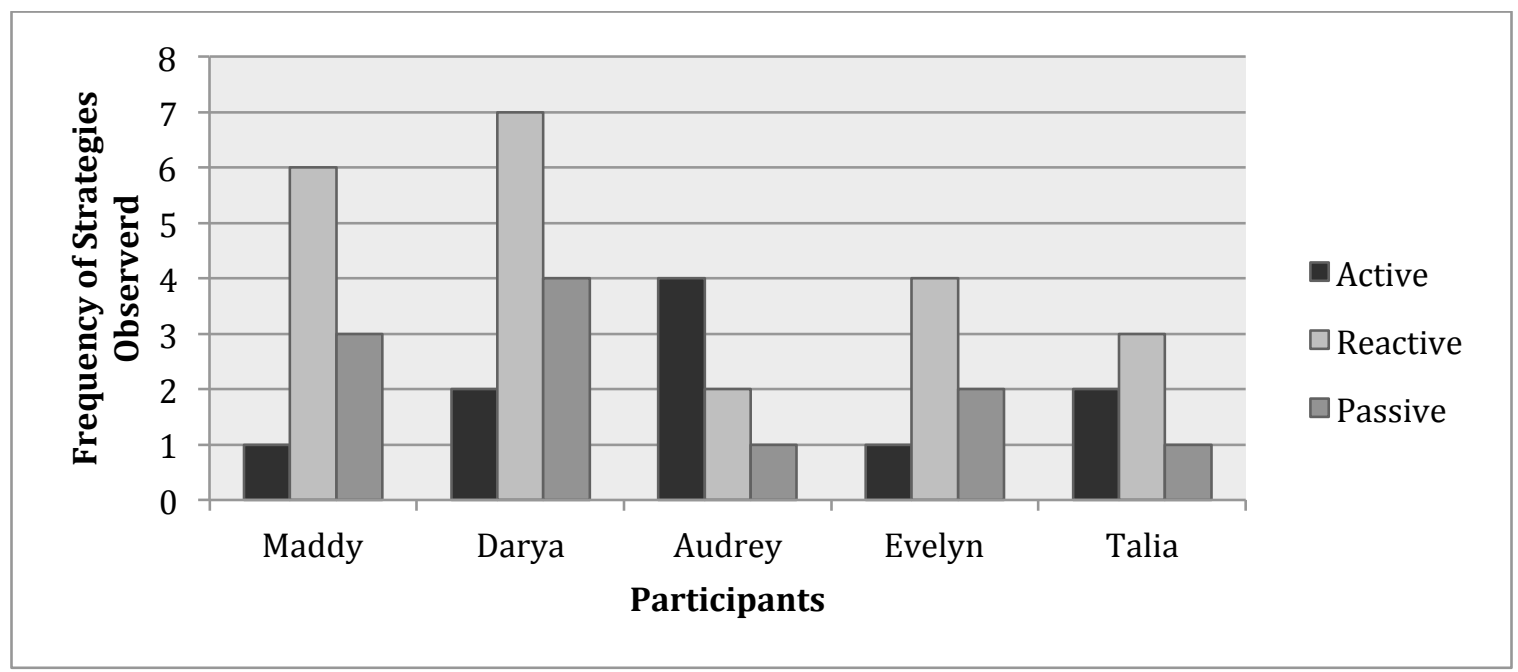

Figure 3. Strategies observed in practice. This figure illustrates the frequency of strategies observed by participant. 
Active strategies. Active strategies are defined as pre-planned, organized activities acted out by educators. There were a number of active strategies that were reported and observed, including socially themed group activities, pairing children, asking for helpers, appreciating differences, and discussing friendship. While the educators in the toddler room only reported using socially themed group activities to promote friendship, pairing children and asking for helpers were also observed in practice. Audrey reported using the most active strategies of all of the educators, and was observed using the most active strategies as well. The educators in the kindergarten room described pairing children, asking for helpers and discussing friendship as strategies to promote friendship. 'Discussing friendship' is the only strategy that directly addressed the concept of friendship with children, and was only described by two participants, Darya and Talia. However, Darya described it as a strategy she used when she worked with preschoolers, not with toddlers. These findings are discussed in greater detail below.

Socially themed group activities. The educators in the toddler and preschool rooms reported using socially themed group activities to promote friendship. These strategies included a tea party in the toddler room, which was described as a group activity in which all of the toddlers were provided with child-sized mugs filled with tea, and brought their mugs outside of the class and "chatted". In the preschool room, Audrey described an activity called a 'friendship circle', which she described as an activity that includes a ball of yarn, and all of the children sitting in a circle. In this activity, the person who is holding the yarn tapes it in front of them, looks around the circle, and chooses somebody to say something nice about. The yarn is then tossed to that person, who tapes the yarn in front of them and says a compliment to another person. After the 
activity is finished, the yarn has created a design. The educators in the kindergarten room did not describe any socially themed group activities.

Within each classroom, socially themed group activities were observed in the form of group art, snack, and circle time. The educators did not report these activities when they listed strategies to promote friendship, possibly because they did not perceive this activity to be specifically aimed at promoting friendship. However, instances that appeared to promote friendship were observed in the toddler and preschool room. For example, in the toddler room, Maddy would sing a song and name each child, and comment on something they are doing in the group or something about them. Similarly, in the preschool room during circle time, Audrey would oversee an activity where children were asked a question in a conversational matter within a group. This practice was similar to what she described in the 'friendship circle', but more unstructured.

Pairing children. The strategy of pairing children together was reported by educators in the preschool and kindergarten rooms in the form of hand-holding (asking children to hold another child's hand while walking to a new location), sitting side-byside (asking children to sit together), organizing games that require partnership (incorporating an element of cooperation or partnership in programs), and asking children to help other children. Audrey reported using hand holding, sitting side-by-side, and asking children to help other children. While the first two of these strategies were not observed in practice, Audrey was observed twice asking a child to help another child. For example, Audrey was asking a child to clean up, and helped the child ask another child to help her clean up. In an example both reported in the interview and observed in the 
classroom, Audrey asked children to help a child who was new to the classroom, and the children subsequently showed her around and invited her to play.

While the educators in the toddler room did not report pairing children as a strategy, it was observed in their classroom. In one instance, Maddy brought a chair over to where another child was sitting and playing with a cash register. She guided the child to sit on the chair next to the other child to play. However, Maddy left soon after, and the child who was originally playing with the cash register left to follow the staff. Pairing children together in the preschool room and kindergarten room appeared to be a beneficial strategy for promoting friendship, although in the toddler room it appeared that educators needed to continue facilitating the interaction after pairing children together. Many of the toddlers tended to follow educators when they moved to a new area, so it was important for educators to remain with the children to facilitate interactions between the children they pair together.

Discussing friendship. Only two educators described talking about the concept of friendship with children. One of these educators (Talia) described using books to discuss friendship in her classroom, and the other educator (Darya) described using various strategies to discuss friendship when she worked in a preschool class. Both educators planned activities to help discuss friendship to help sort out issues between friends in the classroom. When Talia noticed conflict within her classroom, she said, "we try to help them, we ...read stories and try to explain to them what friendship is". She said, "we read the book to talk about 'how can we ask a friend if we want to play?' or 'how can we say certain things to a friend?" She said these books were helpful because the children could "relate" the issues "to themselves". Thus it appeared that the concept of friendship 
was only introduced into planned activities with older children and to deal with problems in existing friendships.

Reactive strategies. Reactive strategies are categorized as responses to situations to promote friendship. They are not pre-planned like active strategies, but are rather enacted to resolve or facilitate a situation. Reactive strategies were the most commonly reported and observed strategies. Reactive strategies were categorized as being a strategy that was only implemented to react to a situation between children to resolve conflict and/or promote friendship. These strategies included facilitating interactions (i.e. communicating, managing emotions, and problem solving) and positive reinforcement. Educators in the toddler room focused on providing children with language to facilitate interactions, Audrey focused on managing emotions in the preschool room, and the educators in the kindergarten classroom focused on problem solving. Positive reinforcement was observed in all three classrooms, with a focus more on paired or group activities in toddler and preschool room, and individual accomplishments in the kindergarten room. Concerns regarding safety often appeared to undermine the effectiveness of positive reinforcement across the classrooms.

Facilitating interactions. The way in which facilitating interactions was reported by educators differed across participants, and were categorized into three methods of facilitation: 1) helping children communicate (providing language for children who may be struggling or are behaving inappropriately to help children move forward in their social interaction), 2) managing emotions (in an instance where a child has hurt another child's feelings, describe how actions/words can effect how others feel and soothe the child whose feelings are hurt), and 3) problem solving (in situations where children are 
arguing or upset, discuss with the children how the problem can be resolved). Educators in the toddler room described facilitating interactions through helping children communicate. For example, Maddy described:

If I see that someone wants to play with someone and they don't really know how to do it or they're doing it inappropriately like they're just coming up and, you know, hugging someone or grabbing their toy or pushing into their space, I can kind of intervene in that way and say "I see you want to play with or it looks like you want to play with this kid, how about saying 'Can I play with you?' or 'What are you playing?' or 'Do you want to play ...this'”. So I'm kind of giving them language.

Audrey in the preschool room described focusing on managing emotions. For example, she said:

Sometimes the children say "I don't want to hold his hand" and I'm like "Oh, look at his face. He's very sad. You hurt his feelings". And then they're like "oh I did?" and then they're like “woah". They look at the child and they're sad, because they didn't hold her hand... And then they go over and hug them and say, "okay I'll hold you're hand". But it's like this is what happens, you're teaching them empathy.

The educators in the kindergarten room described focusing on problem solving. For example, when Talia described a situation where a child was saying another child is not their friend, she said her first task is to "see whats going on" and "go an discuss" what happened. In contrast to this pattern across the classrooms, Darya from the toddler room also described problem solving when reporting strategies she used to facilitate interaction. When she was describing how she talks to children who are not playing well 
together, she said "you have so much fun together, and that's great, you're close friends, but when you do things that aren't safe then you're showing us that you're not ready to be together". She appears to provide more discussion when facilitating interactions than simply providing words.

The observed strategies for facilitating interactions were consistent with educator's reported strategies. The toddler room educators were observed providing language for the children, Audrey was observed managing and discussing emotions, and the kindergarten room educators were observed problem solving. For example, in the preschool room, a child was yelling through a paper tube, and the tube was directed at another child's face. Audrey asked the child with the tube to lower his voice because otherwise he might hurt the other child's ears. In an example in the kindergarten room, one child hurt another child, and Evelyn approached them and said to the girl who hit "I'm not sure why you hurt Carla. That's not okay". She then discussed why Carla was hit with the two girls, and what to do next time.

Positive reinforcement. Positive reinforcement was reported as a strategy by two of the five educators, Darya in the toddler room and Audrey in the preschool room. This strategy was also commonly observed in the toddler and preschool room. While Maddy also described the importance of positive reinforcement, she described it as being a strategy she had implemented when she worked with kindergarten-aged children. In contrast, Darya said she often notes, "Oh look the two of you are spending so much time together, you seem to be having a lot of fun". Similarly Audrey describes the power of positively commenting on children's actions when they work together. She says, 
"wow!...Look at the two of you working together!" and how the children afterwards are "just beaming" and develop "that sense of pride or accomplishment".

It was common to observe positive reinforcement in the toddler and preschool rooms in regards to social activities. In the toddler room, Darya used a group hug as a reward for children cleaning. When a girl fell and a boy hugged her, the staff in the toddler room said "aww". In the preschool room, a boy and a girl were working together on an art project. The boy would take a sticker, give it to the girl, and put it on a piece of paper. Audrey approached and said, "I like that you are making this together". Then to a third child she said "isn't that nice? Shelly and John are making a project together". Then the third child said she would like to make it too. Based on my observations, it appeared that the children responded to this praise by replicating the actions that received praise.

In the kindergarten room, there appeared to be more comments on individual accomplishments than paired or group work. For example, two children were playing with blocks. Evelyn came up and complimented them on what each one was building separately. She first asked "What are you building Billy?" and then "What are you building Tamara?" even though it appeared to me that the children were building something together. By praising these individual accomplishments, the children may attempt to replicate these individual achievements. If the staff had commented on the two of them working together, the children may perceive this as more praise-worthy than working individually.

Just as children can be praised for an action that may result in the replication of that action later, children who are reprimanded for an action may be less likely to replicate that action later. In my observations, it appeared that educators tended to 
negatively comment on an action if it was unsafe. It was common that instances where children were playing together were interrupted because educators were concerned with the children's safety and noise levels of the classroom. Based on my observations, it appeared that this emphasis placed on safety, while important, often interfered with positively reinforcing group or paired play. For example, in the preschool room, two children were mimicking each other's actions. One child jumped up and down while waiving his arms, and the other child imitated. They were close together and at times would collide into each other while laughing. Eventually, Audrey intervened and asked the children to stop. In my observations, I noted that it appeared the staff felt that playing with "each other's bodies", as I had heard them call it, is unsafe and they should move on to another activity. According to the literature, mimicking actions and playing together is part of how young children make friends (Engdahl, 2012). Thus, it is suggested here that educators be mindful of how they intervene when children's actions are deemed unsafe. It may be important to ensure that these limitations are always followed by an explanation and as well as redirection to a safer paired activity.

Passive strategies. Passive strategies are characterized as indirectly promoting friendship or promoting friendship through inaction. Passive strategies were the least popular across participants. These strategies are characterized by their subtlety and may not require any action from the educators. The two strategies that were characterized as passive that were described by and observed in educators were observing and modeling. When an educator described observing, they stated that they may or may not intervene in a situation. The actual strategy of observing is passive because it does not require an action from the educator for it to be enacted. Similarly, modeling was described as 
displaying expected behaviour to provide an example for children. It is a passive strategy because it is neither a preplanned activity nor a reaction to a situation, but rather a way of being within the classroom. These strategies were described as being used in the toddler room and the kindergarten room, but Audrey did not mention this strategy in her classroom. However, both observing and modeling were witnessed during the observations within all three classrooms.

Observing. The strategy of 'observing' was reported by three educators: Maddy, Darya, and Talia. Thus, both educators in the toddler room described observing children as a strategy to promote friendship. All three of the educators also described 'observation' as an essential part of their role as an educator. Maddy said, "I think that with toddlers a lot of it is observing". Likewise, Talia says "I try and step back a lot to try and observe, see what they're doing, if I notice a bond between them I kind of step back and observe and see where it's going"

All three of the educators stated that they use observation to determine whether or not they need to intervene in a situation or if the children can sort out a problem themselves. Then, if they do need to intervene, they "step back" again to see if the situation has improve or if they need to intervene again. According to Maddy,

They don't have the language always to enter into social situations so I feel that part of my role is to watch and I see that someone wants to play with someone and they don't really know how to do it or they're doing it inappropriately ... and then I can kind of intervene.

Darya described how she often "steps back" from situations to observe what is happening. She said, "not just letting go and saying 'whatever, the children will figure it 
out'. Sometimes you do have to step back ... but that's all part of the strategies". When there is conflict, Talia says, "I will approach that situation and facilitate and then I'll step back again just to see... I don't just say 'okay its great now you guys can go play!' I try to see if the child wants to go back...And then I step back again and just linger around that area just for a bit before I move on".

The use of observation could be beneficial to ensure that children's abilities are accurately appraised. As was previously discussed, Maddy and Darya both believed friendship existed in their classroom by Audrey was resistant to this perception. Both Maddy and Darya reported using observation as a strategy in their classroom and, based on their observations, perceived that friendship occurred in their classroom. For example, the tea party was planned for their classroom because the educators had noticed that the children enjoyed social gatherings. Darya said, "a couple months ago we thought our children were really, in a lot of things they were doing, based on our observations, it was about belonging to the group...so then we did a lot of things, like we had a tea party".

Modeling. Three of the five educators emphasized in their interviews the importance of modeling when promoting friendship. Darya, Evelyn and Talia describe how they hope by modeling certain behaviours the children will learn from them and behave similarly. It is interesting to note that according to the Early Learning for Every Child Today document, 'modeling' is only suggested as a strategy for educators interacting with children over 2.5 years old (Ontario Ministry of Education, 2007). Thus, the educators are following a trend that again aligns with developmental theory, in that Maddy and Audrey from the toddler and preschool room may feel that their children are 
too young for modeling, while Darya, aligning more with new sociology of childhood, may feel that children will benefit from modeling.

Although among the younger classrooms Darya was the only educator to report modeling, it was often observed in each classroom. It also appeared to be effective in the younger classrooms. For example, in the toddler room, a staff who was singing and dancing with a large group of children said "hi Sammy!" to a child who was shyly watching the group sing and dance. All of the children mimicked this in unison, "hi Sammy!" Similarly, a staff in the preschool room exemplified modeling when a little girl was glued to her side. She walked with the girl to a group of children and started asking them friendly questions. The girl who was glued to her side started socializing with the group too. Thus, modeling also appears to be a strategy that can be implemented into the toddler and preschool classrooms as a strategy to promote friendship.

\section{Possible Links Between Educator's Perceptions and Strategies}

Educator's perceptions about friendship were organized onto a continuum ranging from NSC to developmental theory. By comparing where each educator lay on the continuum to their reported and observed strategies it was hoped that possible links could be made between educator's perceptions about friendship and strategies for promoting friendship. It was proposed here that observational strategies implemented by educators aligning with NSC may be effective to identify friendship in the early years and to inform how friendship will be promoted in the classroom. It was also proposed that the active strategies (particularly discussing friendship) implemented more commonly by educators aligning with developmental theory may be effective for teaching children about how friendship differs from other relationships, and to promote inclusive friendship practices. 
Furthermore, it was suggested that facilitating interactions using increased discussion and problem solving, as was often used in preschool and kindergarten classrooms, be implemented into the toddler room as well. It is important to note here that due to the small number of participants in this study, these links are speculative and exploratory in nature. These findings are discussed in further detail below.

\section{Using the term 'friends' in practice: perceptions vs. practice. Generally}

speaking, educators acted consistently with their reports of the use of the word 'friends'. Educator's who believed children were their friends used the term to refer to children as their friends, however two educators who were opposed to using the term were observed using it in practice. This was still consistent with their reports, as both educators stated that they sometimes 'caught themselves' saying friends out of habit.

By comparing educator's perceptions about using the term 'friends' and their observed practice, consistencies between perceptions and practice were analyzed. Three (Darya, Talia and Audrey) of the five educators acted consistently with their perceptions about the use of the term 'friends'. Since Darya and Talia had expressed that they believed using 'friends' to refer to 'educator's friends' was accurate because they are friends with the children, they acted consistently with their perceptions when they were observed using the term to refer to children as their friends. Audrey, who appeared to perceive the term to be inappropriate both for referring to children as "children's friends" and "educator's friends", was not observed using the term in practice, and therefore acted consistently with her perceptions. Evelyn and Maddy, however, had expressed that they disagreed with referring to children as 'educator's friends' and 'children's friends' respectively, but were observed referring to children in such ways. Both educators had 
said that they do at times use the term in practice due to an acquired habit formed from observing previous teachers in practicum.

The consistencies between educator's perceptions and practice may reflect the complexity involved when studying perceptions. As was stated by Kagan (1992), educator's perceptions are but one knowledge base consulted when making a judgement in the classroom. Judgements are also informed by an educator's prior experiences. Thus it appears that while educators may be opposed to using the term 'friends' to refer to “children's friends", they picked up this practice when learning to be an early childhood educator and habitually included it into their practice. However, the educators who used the term unintentionally or habitually appeared to be aware of this, as they 'caught themselves' saying the term despite their negative perception of the term. Thus these educators may be in a mode of transition from using this word in practice to no longer using it, as they appear to be attempting to stop its use. They also appear to be seeking alternative terms to refer to children that are inclusive and appropriate.

Using observation as a strategy to identify and promote friendship. Both Darya and Maddy emphasized the use of observation in the toddler room. Despite having children in their classroom under the age of three (an age at which children are not typically making friends according to developmental theory), both of these educators perceived that children in their classroom make friends. Thus, both of these educators were placed closer to the NSC side of the continuum. It may be important to note that these educators appeared to use observation to draw conclusions about friendship in their class, rather than rely on developmental theory. Based on their observations, Maddy and Darya deduced that the children in their particular class enjoyed being social, and thus 
programmed the active strategy they called the tea party. They also used observation to inform whether or not to facilitate an interaction between two children. Thus, the passive strategy of observations was used to inform their active and reactive strategies, and also informed their perception that friendship existed in their classroom.

It could be suggested here that the use of observation is a method that promotes a strength-based perspective of children, and a fundamental strategy for informing how friendship can be promoted in a specific classroom. According to Buysse (2003), inclusive teachers have been found to take a more passive role than an active role when promoting friendship (e.g. providing sufficient free choice time, allowing children to form their own friendships, and commenting on the play between friends). This finding supports the use of passive strategies, particularly observation, to inform the perceptions and future strategies implemented to promote friendship. Particularly with children under the age of three, the use of observation may be important to dismantle the assumption placed by developmental theory that friendship does not begin until children are over the age of three. As Darya said,

So we have two others, a boy and a girl, who are now really close, and they are exploring friendship, and you know, doing things together. So, we see it, so that for me is one thing, you've got to look. Observe the children and you know, if you have some myths of your own, prove them wrong.

Using active strategies to discuss and friendship in the classroom. The educator who aligned most with developmental theory (Audrey) also reported most active strategies to promote friendship. Also, the educators in the kindergarten room described active strategies that involved discussing friendship with children. These educators 
planned activities to promote friendship, such as the friendship circle in Audrey's classroom and reading stories about friendship. These strategies may be fundamental to teaching children about how friendship differs from other social relationships. They reflect a focus by the educators on helping children begin to 'make friends'. Salend (1999) emphasized the importance of introducing the concept of friendship into activities to promote inclusive social interaction and friendship. For example, she suggests singing songs about friendship, drawing friends, etc. to instill "an understanding of the meaning and importance of friendship, the qualities of a good friendship, the value of having many friends, the impact of friendship on others, and the problems that some students experience in trying to make friends" (Salend, 1999, p. 10).

It is argued here that these active strategies focused on the topic of friendship that have been implemented at the preschool and kindergarten ages should also be implemented in the toddler room. It appears that at the toddler age, children are being introduced to the word 'friends' by being referred to as friends by educators. It may be advantageous to also begin discussing with toddlers the concept of friendship, and the qualities involved in having a friendship. A combination of active strategies involving friendship as well as reserving the term 'friends' for children who appear to actually be friends (i.e. playing together, displaying care), then toddlers may be more likely to enter preschool with a better understanding of what friendship is.

\section{Using reactive strategies to facilitate friendship in the classroom. Reactive} strategies were identified as the most prominently used strategy both reported and observed. Specifically, facilitating interactions between children was the most common strategy. This strategy appeared to be implemented often, even to ensure that other 
strategies were successful. For example, pairing children together was an active strategy described by educators and observed in practice. In the toddler room, it was observed that pairing children together only appeared to be successful in promoting friendship if educators remained with the children after they were paired together to facilitate their interactions. If the educator left too soon after pairing the children together, a child would often follow the educator or the children would not interact. Thus, the action of intervening between children as they interacted with each other to ensure they were behaving in a friendly way appeared to be fundamental to children's successful interactions. It is suggested here that if any active strategies are implemented within toddler rooms (e.g. pairing children), educators may benefit from ensuring that the subsequent interactions are facilitated. This recommendation is in line with that of Lawhon (1997), who recommends supporting children through their process of friendship development, including reminding children to pay attention to the other child, share, show joy, and respond to requests of the other child.

How educators intervened with social interactions also varied by classroom, with educators in the toddler room focusing on facilitating language, educators in the preschool room focusing on emotions, and educators in the kindergarten room focusing on problem solving. While in the toddler room educators would often give the children language, in the preschool and kindergarten room there was often more discussion regarding the problems at hand and associated emotions. This may be a reflection of educator's expectations of the children within each class as determined by their age. However, Darya was the only educator outside of the kindergarten classroom who reported problem solving with children in her classroom. This may reflect her alignment 
with NSC and less focus on developmental theory. It is proposed here that the furthering of discussion with young children above providing them with language at a young age may be beneficial for toddlers. By beginning to talk about feelings and how to solve problems in toddlerhood, children may learn within their first year in a social environment about the why behind what they are told to say, and will further their understandings of how to act with potential friends.

\section{Summary of Findings}

Early childhood educators used the term 'friends' in practice to refer to groups of children. Educators were opposed to referring to all of the children as 'friends' because they believed that it falsely implied that all children are friends, however some educators believed it was accurate for them to refer to children as 'my friends'. Educators reported that although they questioned the use of the term, they often used it out of habit. In practice, the term 'friends' was used more frequently with younger children than older children, as the frequency was highest for the toddler room, and second highest in the preschool room.

The strategies reported and observed were categorized into active, reactive, and passive strategies. Active strategies were helpful for promoting group play in the classrooms. The activity of 'discussing friendship' was only used in the kindergarten classroom, as no other educators described actually discussing the concept of friendship to children. Reactive strategies were the most frequently reported and observed strategies. When supporting children's interactions, the toddler room focused on supporting communication, the preschool room focused on emotions, and the kindergarten room focused on problem solving. 
Educator's perceptions about children's friendship appeared to align with two theories: new sociology of childhood and developmental theory. Educators who aligned with the new sociology of childhood perspective tended perceive friendship as occurring in their classroom despite their age, while educators who aligned more with developmental theory appeared to perceive friendship occurred in their classroom depending on their age. Educators who aligned more with NSC reported using more passive strategies, specifically observation, to promote friendship in their classroom. Educators who aligned more with developmental theory (in the preschool and kindergarten classrooms) tended to use more active strategies to introduce the concept of friendship to children in their classroom.

\section{Limitations of Study}

The use of observation of educator's interactions with children posed the challenge of accurately interpreting the observed information. It was often difficult to hear what was said in the classroom, as many children and staff were talking at once. As the observation sessions were not recorded, certain situations could have been misinterpreted. It is hoped that the use of multiple observation sessions will account for these possible misinterpretations. Additionally, educators were provided with the interview questions prior to the interview. By doing this, educators were provided the opportunity to formulate their answers. While this may be beneficial because providing educators with questions prior to interview can reduce their level of stress during the interview and allow for more detailed responses, the interview loses an element of candidness (Johnson, 2002). It is important to note here that this pilot study is intended to 
be exploratory, and attempted to provide a glimpse into the subject of educator's

perceptions and strategies for promoting friendship in young children.

\section{Future Research}

This study has identified a need for subsequent research on friendship in children under the age of three using a new sociology of childhood theoretical framework. Further research on how children under the age of three make friends and how educators can support children in this process is needed. Applying a new sociology of childhood theoretical framework to such research will ensure that children's abilities and competencies are recognized. Keeping with new sociology of childhood, a study that combines observations as well as children's voices would be useful to explore how young children come to understand friendship from the child's perspective. This research would help inform early childhood educators on how the concept of friendship can be introduced to children under the age of three.

\section{Conclusion}

Upon review of the research question and findings of this study, it appears that educators do promote friendship in the classroom. They use a multitude of strategies to do so, including active, reactive, and passive strategies. Even educators who feel that friendship may not frequently occur in their classroom due to their children's age do use strategies to promote friendship as well as 'friendliness' in the classroom. Educator's perceptions about children's abilities appeared to be a factor that contributed to how educators promoted friendship in the classroom, whereby educators who aligned more with new sociology of childhood tended to use more passive strategies, and educators who aligned more with developmental theory tended to use more active strategies. 
Overall, educators primarily focused on promoting friendship through helping children interact with others, whether it be by communicating for toddlers, helping preschools react to their emotions, or helping kindergarteners problem solve. Children are learning about friendship in each age group, however it is recommended that the concept of friendship be incorporated in more activities within toddler and preschool-aged groups. This may help clarify for toddlers what exactly a 'friend' is, and allow them to understand the benefits of developing social skills. 


\section{Appendix A}

\section{Educator Consent Agreement}

(Identifying information on the location of ELC has been deleted)

You are being invited to participate in a research study. Please read this consent form so that you understand what your participation will involve. Before you consent to participate, please ask any questions to be sure you understand what your participation will involve.

Study Title: We are all friends here: How do educators promote friendship among young children?

Investigators: This research study is being conducted by Kimberly Orchard and supervised by Dr. Rachel Langford, from the department of Early Childhood Studies at Ryerson University.

If you have any questions or concerns about the research, please feel free to contact Kimberly Orchard at kimberly.orchard@ryerson.ca.

Purpose of the Study: This research project seeks to determine in what ways teaching staff promote friendship among children within the classroom. The researcher hopes to explore this question through interviews with teaching staff and classroom observations. The researcher is aiming to recruit five staff to participate in this project. Any staff who work directly with children within the ELC are eligible for participation. The project is being completed by a graduate student in partial completion of her degree, and results will contribute to her major research project.

What Participation Means: Your participation in this project would include: 1) a 30 minute interview with the researcher, and 2) consent to conduct unobtrusive observations within your class for one week.

1) Interviews: The half-hour interview will be conducted at the time of your choosing (either during or after work hours), in a secluded area on campus. In this interview, the researcher will ask questions about what you think your role is in promoting friendship in your classroom. You will also be asked about any practices you may use to promote friendship. The interview will be conducted before the initiation of observations. The interview will be audio recorded. Following the interview, the audio recordings will be transcribed by the researcher and emailed to you. At this point, you will have the opportunity to omit any information you think does not accurately reflect your thoughts or practice.

2) Observations: Observations will be conducted to explore how friendship is promoted within the classroom. The observations will be unobtrusive, with the 
goal being to observe the classroom in its natural state. The researcher will use any resources within the classroom to remain unobtrusive. In classrooms with two-way mirrors, the researcher will remain behind the mirrors and observe from outside of the classroom. Observations will be conducted 5 times over the course of five days. Each observation will be one hour long, and will be conducted at varied times throughout the day. The purpose of conducting multiple observations at different times of the day is to capture a more complete understanding of the classroom. Observations will be documented using paper and pen, and no recordings or videos will be made. Staff and child identities will be kept confidential throughout the study. Following the observations, the researcher's field notes will be emailed to you, at which point you may omit any information that you feel does not accurately represent your classroom.

Potential Risks as a Participant: If you choose to participate in this study, there is a risk that you might feel uncomfortable or anxious with the interview and/or observations used in this study. In recognizing this, it is important to note that you may stop participation or simply skip questions at any time if you feel uncomfortable. Further, it is important to know that the researcher is not intending to pass judgement, but rather would like to learn from you. Any risk of personal identity being revealed will be minimized by the researcher taking extra precautions to ensure your confidentiality. As previously stated, you will have the opportunity to read over the interview transcripts and observation field notes to ensure you are comfortable with the data collected within this study. In terms of benefits, there are no direct benefits of participating in this project. You will also be provided with a final draft of the major research project to ensure you are comfortable with the final analysis.

Confidentiality: Procedures to protect the confidentiality of you and your students will be taken. To ensure that your name remains confidential, numerical codes will be assigned before data collection. The corresponding code to your name will be kept separate from the data. For final project, you can decide if you would like your real name to be used or not, otherwise a pseudonym will be assigned. All data will be locked, and only the principal researcher (Kimberly Orchard) and the supervisor (Rachel Langford) will have access to this data. Further, all information containing identifying data will be destroyed/deleted. The researcher will not discuss this information with other people, and all information provided to the researcher will be safeguarded. However, there are certain legal or ethical circumstances that might require a breach of confidentiality. If an exceptional circumstance presents itself, for example an indication of child abuse, the researcher will have a legal obligation to report this to protect the safety of the child. Transcribed data and written notes will be saved for one year after the completion of the researcher's project. This data will be kept in case it is needed for further review of the project, but will be destroyed after one year to optimize the safeguarding of confidentiality for participants. Following audio recording, you have the right to review and edit the recordings or transcripts. You will be provided with a final draft of the project for the opportunity to omit any information you do not want published. 
Voluntary Participation and Withdrawal: If you choose to participate in this study, your participation is completely voluntary. You may withdraw from the study at any time. If you withdraw, your data will not be used for analysis unless you specify that it can be. Withdrawal from the study will not influence future relations with the Early Learning Centre, or the investigator (Kimberly Orchard) of this study.

Questions: If you have any questions about the research now, please ask. If you have questions later about the research, you may contact Kimberly Orchard at kimberly.orchard@ryerson.ca, or Dr. Rachel Langford at rlangfor@ryerson.ca.

Please sign here if you wish to provide consent to participate in this study:

Name (Please Print)

$$
\text { Signature }
$$

Date

Please sign here if you wish to provide consent for the researcher to audio-record your interview: 


\section{Appendix B}

\section{Educator Interview Protocol}

Just to remind you, this interview is 30 minutes long. I have set a timer so as not to go over our allotted time. I would also like to remind you that this interview is being recorded, and will be transcribed later and emailed to you to ensure you are comfortable with what was said.

I would like to begin by stating that I am not trying to make any presumptions about your teaching style, I am simply trying to understand if/how friendship is promoted in your classroom. I will start by asking questions about your beliefs about friendship and your role in relation to facilitating friendship in the classroom. Then we will move on to questions about practices that promote friendship.

1. What do you think about friendship in your classroom?

2. Do you consider it part of your role as an educator to promote friendship in your classroom?

3. Do you try to promote friendship in your classroom?

4. How do you promote friendship in your classroom?

5. Do you have strategies that you use to promote friendship in the classroom?

6. Do you think you are successful in promoting friendship in your classroom?

7. Can you provide me with an example of a time where you tried to promote friendship in your classroom?

8. What do you think about using the term 'friends' to refer to children in the classroom?

9. Is there anything you would like to add that you think is important in relation to this topic?

Thank you very much for participating in this interview. 


\section{Appendix C}

\section{NVivo Sub-Codes}

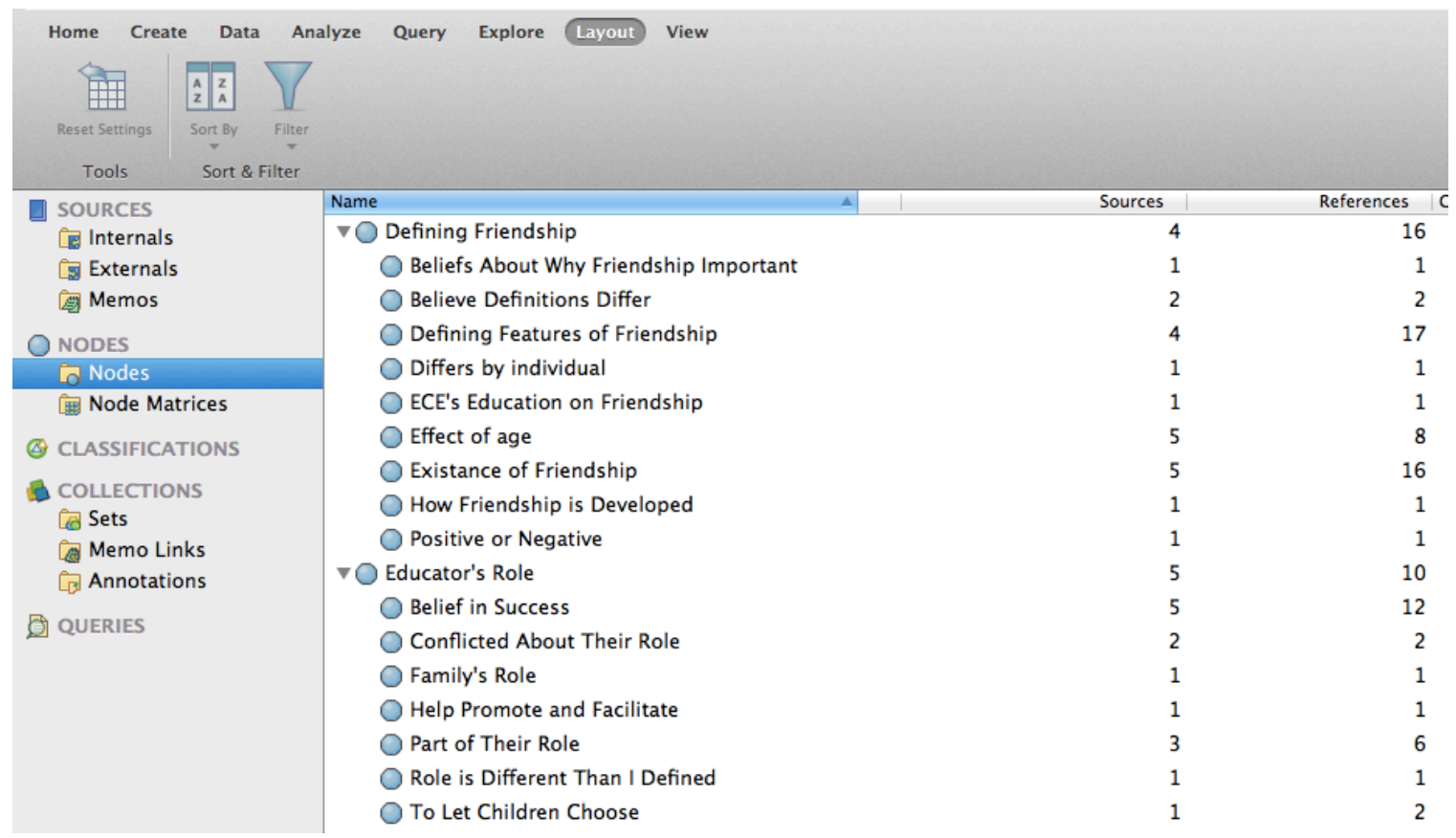

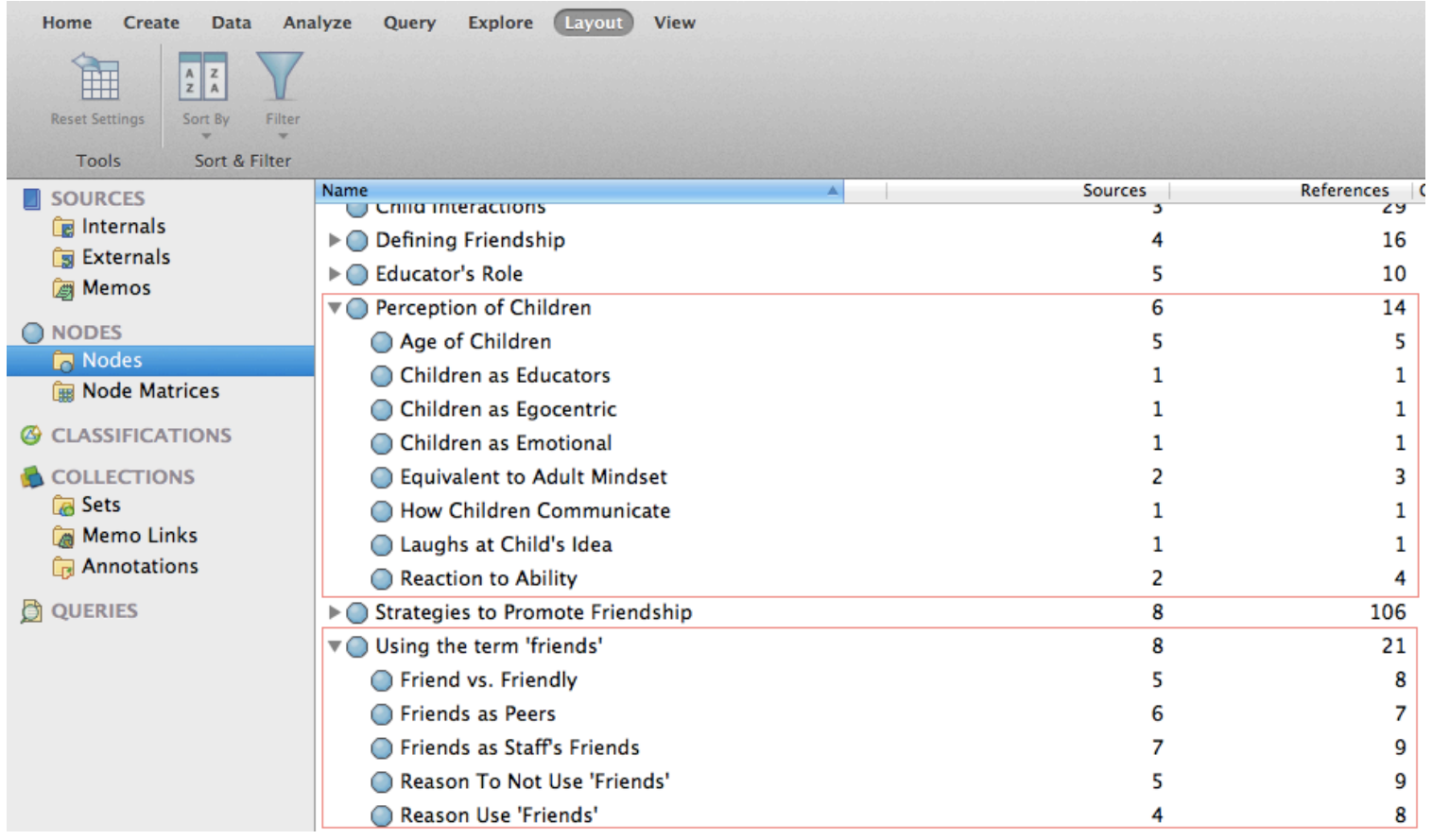




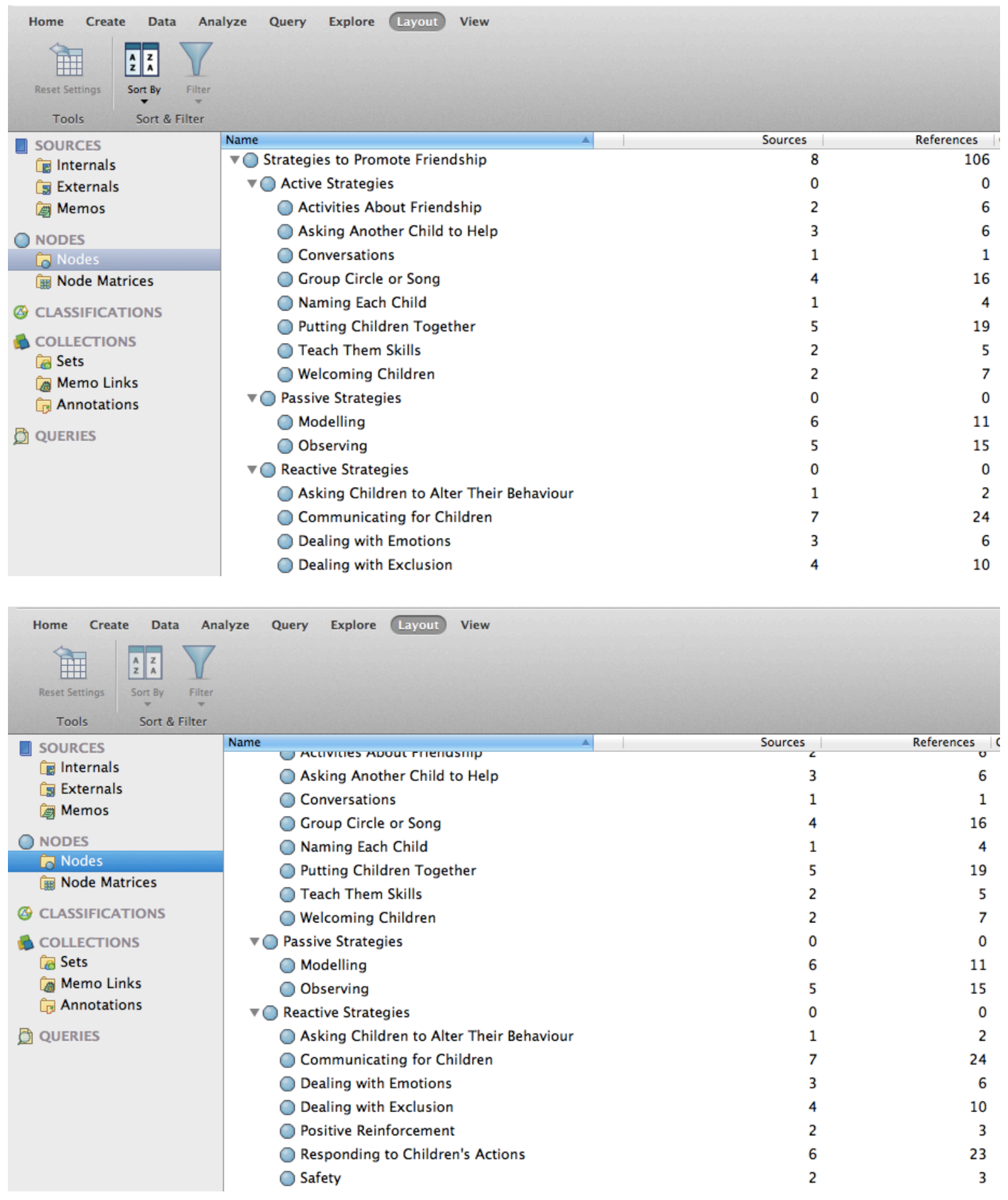




\section{Appendix D}

\section{Description of Strategies Reported}

\begin{tabular}{|c|c|c|}
\hline Tea Party & $\begin{array}{l}\text { A group activity in which } \\
\text { all of the toddlers were } \\
\text { provided with child-sized } \\
\text { mugs filled with tea. The } \\
\text { class brought their mugs } \\
\text { outside of the class, brought } \\
\text { their mugs, and "chatted". }\end{array}$ & $\begin{array}{l}\text { Maddy - Toddler room } \\
\text { Darya - Toddler room }\end{array}$ \\
\hline Friendship Circle & $\begin{array}{l}\text { An activity that includes a } \\
\text { ball of yarn, and all of the } \\
\text { children sitting in a circle. } \\
\text { The person who is holding } \\
\text { the yarn tapes its in front of } \\
\text { them, looks around the } \\
\text { circle, and chooses } \\
\text { somebody to say something } \\
\text { nice about. The yarn is then } \\
\text { tossed to that person, who } \\
\text { tapes the yarn in front of } \\
\text { them and says a compliment } \\
\text { to another person. After the } \\
\text { activity is finished, the yarn } \\
\text { has created a design. }\end{array}$ & Audrey - Preschool room \\
\hline Hand holding & $\begin{array}{l}\text { Asking children to hold } \\
\text { another child's hand while } \\
\text { walking to a new location }\end{array}$ & Audrey - Preschool room \\
\hline Sitting side-by-side & $\begin{array}{l}\text { Having children sit next to } \\
\text { each other during snack or } \\
\text { art time. Allowing them to } \\
\text { choose who to sit beside. }\end{array}$ & Audrey - Preschool room \\
\hline $\begin{array}{l}\text { Organizing games that } \\
\text { require partnership }\end{array}$ & $\begin{array}{l}\text { When programing, ensuring } \\
\text { that there is an element of } \\
\text { cooperation or partnership. }\end{array}$ & Talia - Kindergarten room \\
\hline Asking for help & $\begin{array}{l}\text { Asking a child to help } \\
\text { another child with } \\
\text { something. }\end{array}$ & $\begin{array}{l}\text { Audrey - Preschool room } \\
\text { Evelyn - Kindergarten } \\
\text { room }\end{array}$ \\
\hline Discussing Friendship & $\begin{array}{l}\text { Incorporating the concept of } \\
\text { friendship into activities } \\
\text { such as songs and books. }\end{array}$ & $\begin{array}{l}\text { Evelyn - Kindergarten } \\
\text { room }\end{array}$ \\
\hline $\begin{array}{l}\text { Helping Children } \\
\text { Communicate }\end{array}$ & $\begin{array}{l}\text { Providing language for } \\
\text { children who may be } \\
\text { struggling or are behaving } \\
\text { inappropriately to help }\end{array}$ & $\begin{array}{l}\text { Maddy - Toddler room } \\
\text { Darya - Toddler room }\end{array}$ \\
\hline
\end{tabular}




\begin{tabular}{|c|c|c|}
\hline & $\begin{array}{l}\text { children move forward in } \\
\text { their social interaction }\end{array}$ & \\
\hline Managing Emotions & $\begin{array}{l}\text { In an instance where a child } \\
\text { has hurt another child's } \\
\text { feelings, describe how } \\
\text { actions/words can effect } \\
\text { how others feel and soothe } \\
\text { the child whose feelings are } \\
\text { hurt }\end{array}$ & Audrey - Preschool room \\
\hline Problem Solving & $\begin{array}{l}\text { In situations where children } \\
\text { are arguing or upset, discuss } \\
\text { with the children how the } \\
\text { problem can be resolved }\end{array}$ & $\begin{array}{l}\text { Evelyn - Kindergarten } \\
\text { room } \\
\text { Talia - Kindergarten room } \\
\text { Darya - Toddler room }\end{array}$ \\
\hline Positive Reinforcement & $\begin{array}{l}\text { Commenting in a positive } \\
\text { way on children displaying } \\
\text { aspects of friendship }\end{array}$ & $\begin{array}{l}\text { Darya - Toddler room } \\
\text { Audrey - Preschool room }\end{array}$ \\
\hline Observation & $\begin{array}{l}\text { Stepping back and watching } \\
\text { children to gage their needs } \\
\text { in relation to promoting } \\
\text { friendship. Providing space } \\
\text { for children to interact and } \\
\text { only intervening when it } \\
\text { appears necessary. }\end{array}$ & $\begin{array}{l}\text { Maddy - Toddler room } \\
\text { Darya - Toddler room } \\
\text { Talia - Kindergarten room }\end{array}$ \\
\hline Modeling & $\begin{array}{l}\text { Acting as an example for } \\
\text { how to behave with friends }\end{array}$ & $\begin{array}{l}\text { Darya - Toddler room } \\
\text { Evelyn - Kindergarten } \\
\text { room } \\
\text { Talia - Kindergarten room }\end{array}$ \\
\hline
\end{tabular}




\section{References}

Ashton, P. T. \& Webb, R. B. (1986). Making a difference: Teacher's sense of efficacy and student achievement. New York: Longman.

Atkinson P. (1992) Understanding Ethnographic Texts. Sage, Newbury Park, CA.

Bagwell, C. L., Newcomb, A. F., \& Bukowski, W. M. (1998). Preadolescent friendship and peer rejection as predictors of adult adjustment. Child Development, 69(1), 140-153. doi:10.1111/j.1467-8624.1998.tb06139.x

Barron, I. (2011). The shadows of difference: Ethnicity and young children's friendships. Race Ethnicity and Education, 14(5), 655-673. doi:10.1080/13613324.2010.547848

Basit, T. N. (2010). Conducting research in educational contexts. London, UK: Continuum International Publishing Group.

Berndt, T. J., Hawkins, J. A., \& Jiao, Z. (1999). Influences of friends and friendships on adjustment to junior high school. Merrill-Palmer Quarterly, 45, 13.

Berndt, T. J. (2002). Friendship quality and social development. Current Directions in Psychological Science, 11, 7-10.

Braun, V., \& Clarke, V. (2006). Using thematic analysis in psychology. Qualitative Research in Psychology, 3(2), 77-101. doi:10.1191/1478088706qp063oa

Brown, W., Odom, S., \& Conroy, M. (2001). An intervention hierarchy for promoting young children's peer interactions in natural environments. Topics in Early Childhood Special Education, 21(3), 162-175. doi:10.1177/027112140102100304

Brown, W. H., Odom, S. L., Li, S., \& Zercher, C. (1999). Ecobehavioral assessment in early childhood programs: A portrait of preschool inclusion. The Journal of Special Education, 33(3), 138-153. 
Burk, D. I. (1996). Understanding friendship and social interaction. Childhood Education, 72(5), 282.

Buysse, V., Wesley, P., \& Bryant, D. (1999). Quality of early childhood programs in inclusive and noninclusive settings. Exceptional Children, 65, 301.

Buysse, V. (1993). Friendships of preschoolers with disabilities in community-based child care settings. Journal of Early Intervention, 17(4), 380-395. doi:10.1177/105381519301700404

Buysse, V., Goldman, B. D., \& Skinner, M. L. (2003). Friendship formation in inclusive early childhood classrooms: What is the teacher's role? Early Childhood Research Quarterly, 18(4), 485-501.

Corsaro,W. A. \& Fingerson, L. 2003. 'Development and Socialization in Childhood.' In J. Delamater (Eds), Handbook of Social Psychology (125-155). New York: Kluwer Academic/Plenum Publishers.

Crabtree B, Miller W. Doing Qualitative Research. $2^{\text {nd }}$ edn. Thousand Oaks, California: Sage 1999;18-20.

Creswell, J. (2014). Research design: Qualitative, quantitative, and mixed method approaches. (4th ed.). Thousand Oaks, CA: Sage Publications.

Dahlberg, G., Moss, P., \& Pence, A., R. (2007). Constructing early childhood: What do we think it is? Beyond quality in early childhood education and care: Languages of evaluation (pp. 43-61). New York: Routledge.

Davies, D. (2011). Child development: A practitioner's guide (Third. ed.) Guilford Press. DiCicco-Bloom, B., \& Crabtree, B. F. (2006). The qualitative research interview. Medical Education, 40(4), 314-321. doi:10.1111/j.1365-2929.2006.02418.x 
Dunn, J., \& Cutting, A. L. (1999). Understanding others, and individual differences in friendship interactions in young children. Social Development, 8(2), 201-219. doi:10.1111/1467-9507.00091

Engdahl, I. (2012). Doing friendship during the second year of life in a swedish preschool. European Early Childhood Education Research Journal, 20(1), 83-98. doi:10.1080/1350293X.2012.650013

Engle, J. M., McElwain, N. L., \& Lasky, N. (2011). Presence and quality of kindergarten children's friendships: Concurrent and longitudinal associations with child adjustment in the early school years. Infant and Child Development, 20(4), 365386. doi:10.1002/icd.706

Evertson, C. M. \& Weade, R. (1989) Classroom management and teaching style: instructional stability and variability in two junior high English classrooms. Elementary School Journal, 89, 379-393

Fawcett, C. A., \& Markson, L. (2010). Similarity predicts liking in 3-year-old children. Journal of Experimental Child Psychology, 105(4), 345-358. doi:10.1016/j.jecp.2009.12.002

Fink, E., Begeer, S., Peterson, C. C., Slaughter, V., \& Rosnay, M. (2015). Friendlessness and theory of mind: A prospective longitudinal study. British Journal of Developmental Psychology, 33(1), 1-17. doi:10.1111/bjdp.12060

Gleason, T., Gower, A., Hohmann, L., \& Gleason, R. (2005). Temperament and friendship in preschool-aged children. International Journal of Behavioral Development, 29(4), 336-344. doi:10.1177/01650250544000116 
Gleason, T., \& Hohmann, L. M. (2006). Concepts of real and imaginary friendships in early childhood. Social Development, 15(1), 128-144. doi:10.1111/j.14679507.2006.00333.x

Grieshaber, S. J. (2007). The sociology of childhood. Early childhood education: An international encyclopaedia () Praeger Publishers.

Guralnick, M. J., Neville, B., Hammond, M. A., \& Connor, R. T. (2007). The friendships of young children with developmental delays: A longitudinal analysis. Journal of Applied Developmental Psychology, 28(1), 64-79. doi:10.1016/j.appdev.2006.10.004

Hallinan, M. T. \& Smith, S. S. (1989). Classroom characteristics and student friendship cliques. Social Forces, 67, 898-919.

Hay, D. F., Payne, A., \& Chadwick, A. (2004). Peer relations in childhood. Journal of Child Psychology and Psychiatry, 45(1), 84-108. doi:10.1046/j.00219630.2003.00308.x

Hestenes, L., Cassidy, D., Jonghee, S., \& Hegde, A. (2008). Quality in inclusive preschool classrooms. Early Education \& Development, 19(4), 519-540. doi:10.1080/10409280802230973

Hollingsworth, H. L., \& Buysse, V. (2009). Establishing friendships in early childhood inclusive settings: What roles do parents and teachers play? Journal of Early Intervention, 31(4), 287-307. doi:10.1177/1053815109352659

Howes, C. (1983). Patterns of friendship. Child Development, 54(4), 1041-1053. 
Hoyte, F., Torr, J., \& Degotardi, S. (2014). The language of friendship: Genre in the conversations of preschool children. Journal of Early Childhood Research, 12(1), 20-34. doi:10.1177/1476718X13492941

James, A. (2004). Understanding childhood from an interdisciplinary perspective: Problems and potentials. In P. B. Pufall, \& R. Unsworth P. (Eds.), Rethinking childhood (pp. 25-37). New Brunswick, NJ: Rutgers University Press.

James, A., \& Prout, A. (1997). Constructing and reconstructing childhood: Contemporary issues in the sociological study of childhood Falmer Press.

Johnson J. In-depth interviewing. In: Gubrium J, Holstein J, eds. Handbook of Qualitative Research. Thousand Oaks, California: Sage 2002;103-19.

Kagan, D. M. (1992). Implications of research on teacher belief. Educational Psychologist, 27(1), 65.

Kerns, K. (2000). Types of preschool friendships. Personal Relationships, 7(3), 311-324. doi:10.1111/j.1475-6811.2000.tb00019.x

Kontos, S. (1999). Preschool teachers' talk, roles, and activity settings during free play. Early Childhood Research Quarterly, 14(3), 363-382.

Ladd, G. W. (1990). Having friends, keeping friends, making friends, and being liked by peers in the classroom: Predictors of children's early school adjustment? Child Development, 61(4), 1081-1100. doi:10.2307/1130877

Ladd, G. W., \& Troop-Gordon, W. (2003). The role of chronic peer difficulties in the development of children's psychological adjustment problems. Child Development, 74(5), 1344-1367. doi:10.1111/1467-8624.00611 
Laghi, F., Baiocco, R., Di Norcia, A., Cannoni, E., Baumgartner, E., \& Bombi, A. S. (2014). Emotion understanding, pictorial representations of friendship and reciprocity in school-aged children. Cognition and Emotion, 28(7), 1338-1346. doi:10.1080/02699931.2014.881779

Lara-Cinisomo, S., Fuligni, A. S., Ritchie, S., Howes, C., \& Karoly, L. (2008). Getting ready for school: An examination of early childhood educators' belief systems. Early Childhood Education Journal, 35(4), 343-349. doi:10.1007/s10643-007$0215-2$

Laursen, B., \& Hartup, W. W. (2002). The origins of reciprocity and social exchange in friendships. New Directions for Child and Adolescent Development, 2002(95), 2740. doi:10.1002/cd.35

LeCompte, M. D. (2000). Analyzing qualitative data. Theory into Practice, 39(3), 146154. doi:10.1207/s15430421tip3903_5

Leech, N. L., \& Onwuegbuzie, A. J. (2011). Beyond constant comparison qualitative data analysis: Using NVivo. School Psychology Quarterly, 26(1), 70-84. doi:http://dx.doi.org/10.1037/a0022711

Matthews, S. H. (2007). A window on the 'New' sociology of childhood. Sociology Compass, 1(1), 322-334. doi:10.1111/j.1751-9020.2007.00001.x

Meyer, L., \& Ostrosky, M. (2014). Measuring the friendships of young children with disabilities: A review of the literature. Topics in Early Childhood Special Education, 34(3), 186-196. doi:10.1177/0271121413513038

Mulhall, A. (2003). In the field: Notes on observation in qualitative research. Journal of Advanced Nursing, 41(3), 306-313. doi:10.1046/j.1365-2648.2003.02514.x 
Newcomb, A. F., \& Bagwell, C. L. (1995). Children's friendship relations: A metaanalytic review. Psychological Bulletin, 117(2), 306-347. doi:http://dx.doi.org/10.1037/0033-2909.117.2.306

Niffenegger, J. P., \& Willer, L. R. (1998). Friendship behaviors during early childhood and beyond. Early Childhood Education Journal, 26(2), 95-99.

Ontario Ministry of Education. (2007). Early learning for every child today: A framework for ontario early childhood settings (ELECT). Toronto: Best Start Expert Panel on Early Learning.

Ontario Ministry of Education. (2014). How does learning happen? Ontario's pedagogy for the early years. Toronto: Queen's Printer for Ontario.

Pedersen, S., Vitaro, F., Barker, E. D., \& Borge, A. I. H. (2007). The timing of middlechildhood peer rejection and friendship: Linking early behavior to early-adolescent adjustment. Child Development, 78(4), 1037-1051. doi:10.1111/j.14678624.2007.01051.x

Peterson, P. L., Fennema, E., Carpenter, T. P. \& Loef, E. (1989). Teacher's pedagogical content beliefs in mathematics. Cognition and Instruction, 6(1) 1-40.

Pittinsky, M., \& Carolan, B. V. (2008). Behavioral versus cognitive classroom friendship networks: Do teacher perceptions agree with student reports? Social Psychology of Education, 11(2), 133-147. doi:10.1007/s11218-007-9046-7

Qvortrup, J., 1994. Childhood matters: an introduction. In: J. Qvortrup, M. Bardy, G. Sgritta and H. Wintersberger, eds. Childhood matters: social theory, practice and politics. Aldershot: Avebury, 1-24. 
Rimm-Kaufman, S. E., Pianta, R. C., \& Cox, M. J. (2000). Teachers' judgments of problems in the transition to kindergarten. Early Childhood Research Quarterly, 15(2), 147-166. doi:10.1016/S0885-2006(00)00049-1

Sakyi, K. S., Surkan, P. J., Fombonne, E., Chollet, A., \& Melchior, M. (2015). Childhood friendships and psychological difficulties in young adulthood: An 18-year followup study. European Child \& Adolescent Psychiatry, 24(7), 815-826. doi:10.1007/s00787-014-0626-8

Salend, S. J. (1999). Facilitating friendships among diverse students. Intervention in School and Clinic, 35(1), 9-15. doi:10.1177/105345129903500102

Stone, L. L., Giletta, M., Brendgen, M., Otten, R., Engels, R. C. M. E., \& Janssens, J. M. A. M. (2013). Friendship similarities in internalizing problems in early childhood Elsevier. doi:10.1016/j.ecresq.2012.12.003

Takei, Y., Johnson, M. P., \& Clark, M. E. (1998). Academic achievement and impression management as factors in the grading of white junior high pupils. Sociological Perspectives, 41, 27-48.

Tilley, S. A., \& Powick, K. D. (2002). Distanced data: Transcribing other people's research tapes. Canadian Journal of Education / Revue Canadienne De l'Éducation, $27(2 / 3), 291-310$.

Tisdall, E. K. M., \& Punch, S. (2012). Not so 'new'? looking critically at childhood studies. Children's Geographies, 10(3), 249-264.

doi:10.1080/14733285.2012.693376 
van Hoogdalem, A., Singer, E., Eek, A., \& Heesbeen, D. (2013). Friendship in young children: Construction of a behavioural sociometric method. Journal of Early Childhood Research, 11(3), 236-247. doi:10.1177/1476718X13488337

Webster, A. A., \& Carter, M. (2007). Social relationships and friendships of children with developmental disabilities: Implications for inclusive settings. A systematic review. Journal of Intellectual and Developmental Disability, 32(3), 200-213. doi:10.1080/13668250701549443

Werebe, M., \& Baudonniere, P. (1988). Friendship among preschool children. International Journal of Behavioral Development, 11(3), 291-304. doi:10.1177/016502548801100301

Whaley, K., \& Rubenstein, T. (1994). How toddlers `do' friendship: A descriptive analysis of naturally occurring friendships in a group child care setting. Journal of Social and Personal Relationships, 11(3), 383-400.

doi:10.1177/0265407594113005

Wheeldon, J., \& Faubert, J. (2009). Framing experience: Concept maps, mind maps, and data collection in qualitative research. International Journal of Qualitative Methods, 68-83.

Zahorik, J. A. (1987). Teachers' collegial interactions: An exploratory study. Elementary School Journal, 87, 385-396 